\title{
PREFERENCE OF TREE SPECIES FOR TROPICAL FOREST ENVIRONMENTS
}

\author{
ARAÚJO, S. N. ${ }^{1}-$ SILVA, A. F. ${ }^{2}-$ COSTA, T. C. C. DA ${ }^{3 *}-$ PEREIRA, M. P. R. ${ }^{4}-$ \\ RABELO, M. F. R. ${ }^{2}$ \\ ${ }^{1}$ Universidade Federal de Minas Gerais \\ Avenida Antônio Carlos, 6627, Pampulha, 31270-901 Belo Horizonte, Minas Gerais, Brazil \\ ${ }^{2}$ Empresa de Pesquisa Agropecuária de Minas Gerais \\ Avenida José Cândido da Silveira, 1647, União, 31170-495, Belo Horizonte, \\ Minas Gerais, Brazil \\ ${ }^{3}$ Embrapa Milho e Sorgo \\ Rodovia MG 424 Km 45, 35701-970, Sete Lagoas, Brazil \\ (phone: +55-31-3027-1159; fax: +55-31-3027-1188) \\ ${ }^{4}$ Universidade Federal de Minas Gerais \\ Instituto de Geociências, Avenida Antônio Carlos, 6627, Pampulha, 31270-901 Belo Horizonte, \\ Minas Gerais, Brazil \\ *Corresponding author \\ e-mail: thomaz.costa@embrapa.br; phone: +55-31-3027-1159; fax: +55-31-3027-1188
}

(Received $5^{\text {th }}$ Oct 2016; accepted $28^{\text {th }}$ Jan 2017)

\begin{abstract}
In order to characterize the environment where plant species have better adaptation, one way is to associate species abundance and distribution with environmental parameters. To do this, we worked in a tropical forest fragment, with point-quarter sampling. The sampling points were parameterized by topographic, hydrographic and soil components, using slope, aspect, distance and water body altitude differences, and fertility and grain size parameters. With canonical correlation analysis and principal component we could detect preferences of some species for water supply, which in turn correlates with some grain size and fertility parameters. The environmental variation related to species abundance and distribution allowed the indication, especially associated with water characteristics, of species for ecological restoration.
\end{abstract}

Keywords: species ecology, phytosociology, environmental analysis, multivariate analysis, semideciduous forests

\section{Introduction}

In order to become effective within the ecological precepts, ecological restoration and recovery of degraded areas are issues that require scientific and technological investment. Exploitation of natural resources, agricultural and industrial production and the urban population, with their environmental liabilities, cause impacts that require a task force for reconstruction of natural environments.

There is research about ecological restoration experiencing methodologies with successional processes, phytosociology, and seed rain, among others (Durigan and Dias, 1991; Barbosa et al., 1992; Tabarelli et al., 1993; Palmer et al., 1997; Barbosa and Lieberg, 1998; Kageyama and Gandara, 2001; Rodrigues and Gandolfi, 2001; Rodrigues and Leitão Filho, 2001; Coutinho et al., 2002; Almeida, 2004). However, the use of a restricted floristic diversity base, without considering ecophysiological information, is usual. 
Other factors that hinder ecological restoration activities are growing trends of warming and drought periods (Getirana, 2016), and competition with invasive grasses, contributing to the increased cost and methodological inefficiency.

A requirement to indicate species, improving the survival rate and seedling development in the field, is to know the relationship of the plant species with the natural environment, such as water regime, soil, fertility and topography (Aquino, 2006).

Among the information that aids in survival and development of plant species is adaptation to drained or poorly drained environments, soil acidity tolerance and fertility requirements, phytosociology of the species through horizontal and vertical parameters, sun or shade tolerance, and adaptation to the succession stage. For this information, the phytosociological inventory and environmental characterization are the first data sources (Oliveira Filho et al., 1994).

The soil component may be parameterized by fertility, particle size and soil water dynamics, among others, while the relief can be parameterized by altitude, slope, aspect, plans and curvature profiles. The components to characterize the preferred species environment will be gathered considering soil, geomorphology, geology, hydrology and climate.

However, the preferred environments for species characterization may be more accurate (Carvalho et al., 2005), since variations in the parameters create distinct and abrupt conditions that can only be perceived with increased scale. Thus, the objective was to analyze tree species in a tropical forest fragment, relating them to topographic, hydrographic and soil parameters, for the selection of species according to their ecological characteristics, aiming at restoration actions in similar environments.

The test was conducted at "Parque da Cascata", which belongs to the Environmental Protection Area of "Serra Santa Helena", in Sete Lagoas, Minas Gerais, Brazil, with high vegetative and hydrological importance (Mahé, 2009).

\section{Materials and Methods}

The natural vegetation in this region is savanna with grasslands and enclaves of Atlantic tropical forest (IBGE, 2004). It has been highly degraded or replaced, mainly by pasture.

Soils are grouped into three types: residual soils of metapelitic rocks, colluvial soils and residual soils of limestone, with color ranging from yellow to dark red (Associação de Desenvolvimento Ambiental, 2007).

Climate classification, according to Köppen, is Cwa, i.e., savanna climate with dry winter and rainy summer. The average annual temperature is $21.1{ }^{\circ} \mathrm{C}$; the lowest average temperature is approximately $11.5{ }^{\circ} \mathrm{C}$, recorded in June and July. The highest temperatures are between $28.5{ }^{\circ} \mathrm{C}$ and $30{ }^{\circ} \mathrm{C}$, and occur in January to March and October to December. August and September are the driest months with relative air humidity (RH\%) between 57.6 and 58.8\%. January, February, March and December have the the highest RH (76.2 , 74.3, 74.8 and 76.7\%). The dry season extends from May to September. The total average annual rainfall is $1.384 \mathrm{~mm}$. The average daily evapotranspiration (ETp) is lower in June, $2.7 \mathrm{~mm}$, and higher in October, whose daily average is $4.7 \mathrm{~mm}$ (Gomide et al., 2006).

The Municipal "Parque da Cascata", created by Law 593 on September 27, 1977, has an area of 205 ha, with 92 ha of tropical forest area (ADESA, 2007). The inventoried area is shown in figure (Fig. 1). 


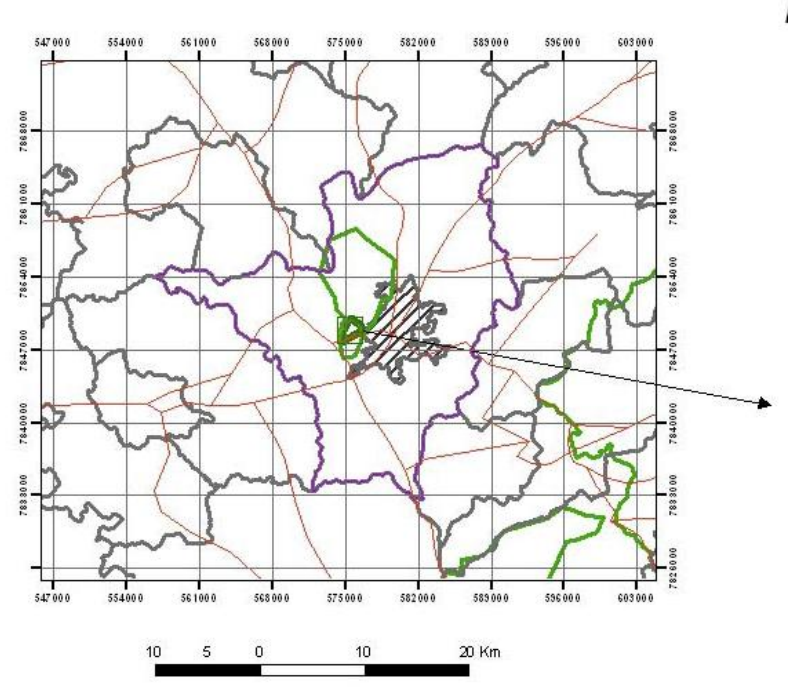

Localização do Parque da Cascata
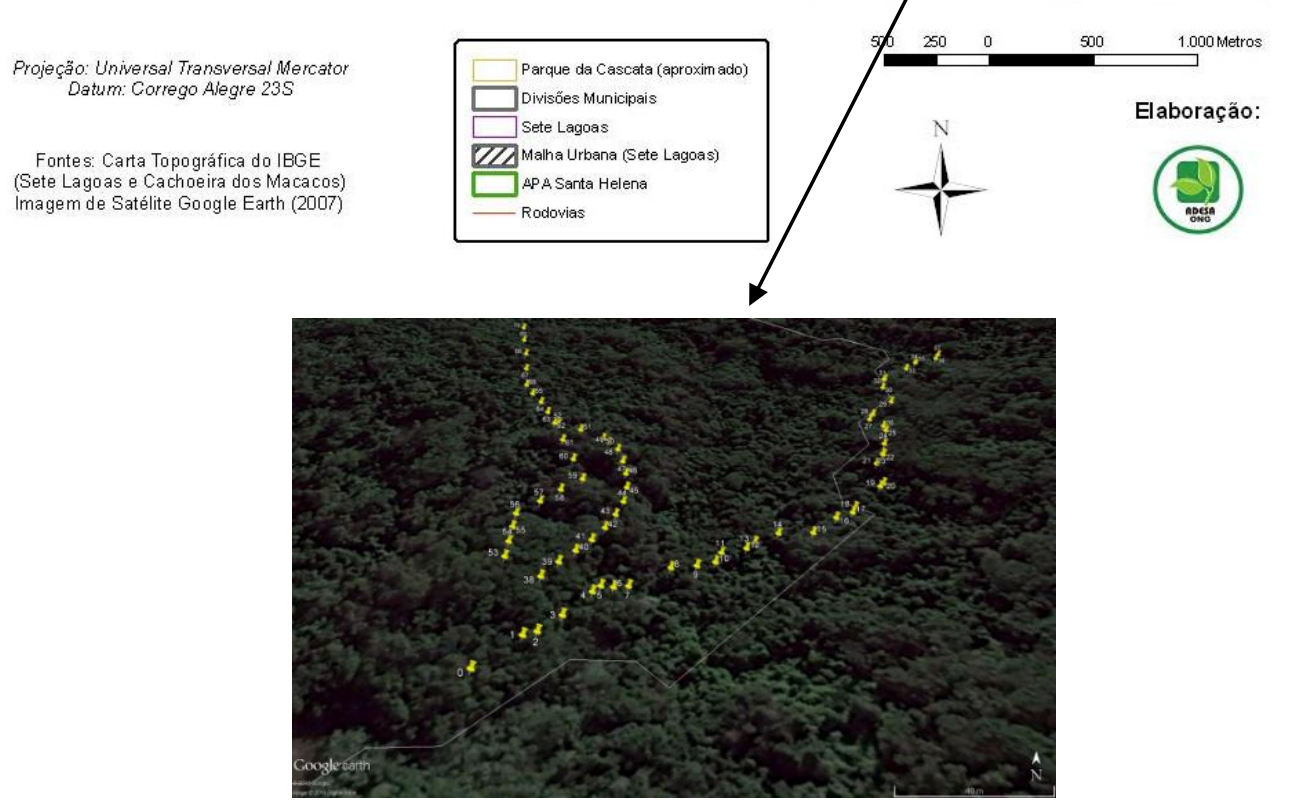

Figure 1. Inventoried quadrant points and the stream in Municipal "Parque da Cascata" (Figure Credit: ADESA, 2007)

A phytosociological inventory was performed through the Point-centred Quarter Method (Cottam and Curtis, 1956). Three transects were drawn (Fig. 1), the first near the watercourse, with 38 points, the second in an intermediate section, with 15 points, and the last transect is farthest from the stream bed, with 18 points.

In the first transect (points 0 to 37), flooded areas prevail near the stream that runs through a part of this transect. The second transect (points 38 to 52) has a forest with lianas, and the third transect (points 53 to 71) is the most remote area of the creek and with higher altitude terrain.

Points were marked at a distance of $10 \mathrm{~m}$, and in each quadrant the nearest tree to the point was selected, measuring the diameter at breast height (DBH), total height using a digital hypsometer and the distance between the point and the tree. All trees with DBH $\geq 5 \mathrm{~cm}$ were considered by collecting botanical material for identification at the 
Herbarium PAMG of the Agricultural Research Company of Minas Gerais (Epamig) and support of the virtual herbarium Tropicos.org (2016), The Field Museum (2016) and The New York Botanical Garden (2007).

The fertile materials were herborized and included in the collection of the PAMG Herbarium /Epamig. The scientific names and phylogenetic relationships follow the APG III classification system (Souza and Lorenzi, 2012), and the confirmation of the scientific names and botanical synonymies were based on the Flora do Brasil 2020 (2016).

The phytosociological parameters of density, dominance, frequency and importance value (IV) were obtained for each species. Environment variables were analyzed with the most abundant species.

Soil samples were collected at points $1,9,19,28,39,43,47,51,56,60,65$ and 68 . We evaluated the following parameters: fertility (Lopes and Guilherme, 2004), particle density, particle size, macro and micro-porosity. With the aid of volumetric rings, thirty-six undisturbed samples were taken at three depths $0-10,10-20,20-30 \mathrm{~cm}$ and, separately, thirty-six deformed soil samples were collected.

The TanDEM-X derived DEM digital elevation model was used (Viana et al., 2015), with a spatial resolution of $12.5 \times 12.5 \mathrm{~m}$. Aspect and slope in degrees were calculated, and the distance of the water body and the difference in altitude between the point and the water body were generated with the help of a GIS (Geographic Information System). The information per point was extracted at the intersection of layers with these data and the quadrant points. The aspect was ranked in faces: North, Northeast, East, Southeast, South, Southwest, West and Northwest, by the framework of the original angles in classes defined by $22.5^{\circ}$ angles. Thus angles that are in classes $0-22.5^{\circ}$ and $337.5^{\circ}-0$ were classified as North face, or $0^{\circ}$. Angles $22.5^{\circ}$ to $67.5^{\circ}$ were classified as Northeast face, or $45^{\circ}$, and so on.

To explore the relationship among the physical medium parameters, we analyzed the correlation between the hydrography, topography, granulometry and soil fertility parameters considering the 12 points and the three soil depths sampling.

Finally, canonical correlation (CCA) multivariate analysis was applied to soil data, correlating with topographic and hydrographic attributes, and analysis of principal components (PCA) was applied to topographic, hydrographic and dendrometric attributes for more abundant species.

\section{Results and Discussion}

\section{Structure of arboreal community}

Two hundred thirty-five individuals belonging to 27 families, 47 genera and 65 species were inventoried. Nine species had only the genus defined and 8 species were not determined, remaining as morpho-species (Tables 1 and 2).

The largest families were Fabaceae with 6 species, Euphorbiaceae, Rubiaceae and Vochysiaceae with 5 species each, Lauraceae and Meliaceae, with 4 species each, and Annonaceae, Apocynaceae, Bignoniaceae and Cannabaceae with 2 species each. The other 14 families were of single-species. The most diverse families are among the 30 most diverse families of Minas Gerais, according to Oliveira Filho et al. (2008a). In general they are also quite representative families regarding number of species in the seasonal forests of Triângulo Mineiro (Araújo et al., 1997; Araújo and Haridasan, 1997), Zona da Mata (Silva et al., 2004), Southern Minas Gerais (Vilela 
et al., 2001; Machado et al., 2004) and in the Brazilian Cerrados (Costa and Araújo, 2001; Pereira-Silva et al., 2004).

Table 1. Species identified with their popular names, conservation status (Cons.) and ecophysiological category (Ecol.). $A B=$ Abundant; $C O=$ Common; $F R=$ Frequent $; V R=$ Very rare; $O C=$ Occasional $; R A=$ Rare $; E R=$ Extremely rare; $C=$ Climax; $P=$ Pioneer; $I S=$ Initial Secondary; $L S=$ Late Secondary (Oliveira Filho et al., 2008a; 2008b; 2008c; 2008d; 2008e)

\begin{tabular}{|c|c|c|c|}
\hline Family/Species & Common name(s) & Cons. & Ecol. \\
\hline \multicolumn{4}{|l|}{ Anacardiaceae } \\
\hline Astronium fraxinifolium Schott ex Spreng & Aroeira-vermelha, gonçalo-alves & $\mathrm{AB}$ & IS \\
\hline \multicolumn{4}{|l|}{ Annonaceae } \\
\hline Annona sylvatica A.St.-Hil. & $\begin{array}{l}\text { Araticum-cagão-macho, araticum-do- } \\
\text { mato, embira }\end{array}$ & FR & IS \\
\hline Guatteria ferruginea A.St.-Hil. & Imbuí-amarela & ER & LS \\
\hline \multicolumn{4}{|l|}{ Apocynaceae } \\
\hline Aspidosperma subincanum Mart. & $\begin{array}{l}\text { Guatambu-vermelho, pau-pereira-do- } \\
\text { campo, perobinha }\end{array}$ & $\mathrm{OC}$ & LS \\
\hline \multicolumn{4}{|l|}{ Bignoniaceae } \\
\hline Jacaranda macrantha Cham. & Caroba, carobão & $\mathrm{OC}$ & IS \\
\hline \multicolumn{4}{|l|}{ Cannabaceae } \\
\hline Celtis pubescens Spreng. & Cipó-espinho, grão-de-galo & FR & $\mathrm{P}$ \\
\hline Trema micrantha $(\mathrm{L}$.$) Blume$ & Crindiúva, pau-pólvora, periquiteira & $\mathrm{OC}$ & $\mathrm{P}$ \\
\hline \multicolumn{4}{|l|}{ Caricaceae } \\
\hline Jacaratia spinosa (Aubl.) A.DC. & $\begin{array}{l}\text { Barrigudo, jacaratiá, mamãozinho, } \\
\text { mamoeiro-de-espinho }\end{array}$ & FR & IS \\
\hline \multicolumn{4}{|l|}{ Euphorbiaceae } \\
\hline Alchornea glandulosa Poepp. & Amor-seco, maria-mole, tapíá & FR & $\mathrm{P}$ \\
\hline Croton urucurana Baill. & Capixingui, urucurana, sangra-d'água & $\mathrm{OC}$ & $\mathrm{P}$ \\
\hline Gymnanthes klotzschiana Müll.Arg. & Branquilho, branquinho, branquio & $\mathrm{AB}$ & IS \\
\hline \multicolumn{4}{|l|}{ Fabaceae } \\
\hline Copaifera langsdorffii Desf. & $\begin{array}{l}\text { Copaíba, copaíba-vermelha, óleo-de- } \\
\text { copaíba, pau-de-óleo }\end{array}$ & $\mathrm{AB}$ & $\mathrm{P}$ \\
\hline Plathymenia reticulata Benth. & Vinhático, vinhático-branco & $\mathrm{CO}$ & $\mathrm{P}$ \\
\hline Platycyamus regnelli Benth. & $\begin{array}{l}\text { Angelim-rosa, folha-de-bolo, pereira, } \\
\text { pereira-vermelha }\end{array}$ & RA & IS \\
\hline \multicolumn{4}{|l|}{ Lauraceae } \\
\hline Cryptocarya aschersoniana $\mathrm{Mez}$ & $\begin{array}{l}\text { Canela-amarela, canela-fogo, canela- } \\
\text { pimenta }\end{array}$ & FR & $\mathrm{P}$ \\
\hline Nectandra megapotamica (Spreng.) Mez & $\begin{array}{l}\text { Canela-cheirosa, canela-ferrugem, } \\
\text { canela-loura, canela-preta }\end{array}$ & RA & IS \\
\hline Ocotea corymbosa (Meisn.) Mez & Canela-corvo, canela-fedorenta & $\mathrm{OC}$ & $\mathrm{P}$ \\
\hline Ocotea velutina (Nees) Rohwer & Canela-amarela, canelão-amarelo & RA & LS \\
\hline \multicolumn{4}{|l|}{ Lecythidaceae } \\
\hline Cariniana estrellensis (Raddi) Kuntze & Estopeira, jequitibá, pau-de-cachimbo & ER & $\mathrm{C}$ \\
\hline \multicolumn{4}{|l|}{ Malvaceae } \\
\hline Luehea grandiflora Mart. & Açoita-cavalo, açoita-cavalo-graúdo & $\mathrm{AB}$ & $\mathrm{P}$ \\
\hline \multicolumn{4}{|l|}{ Melastomataceae } \\
\hline Miconia chamissois Naudin & Maria-preta & VR & $\mathrm{P}$ \\
\hline \multicolumn{4}{|l|}{ Meliaceae } \\
\hline Cabralea canjerana (Vell.) Mart. & Canjerana, cedro-canjerana & VR & IS \\
\hline Guarea guidonia (L.) Sleumer & $\begin{array}{l}\text { Camboatã, canjerana-miúda, cedro- } \\
\text { branco, jitó, marinheiro }\end{array}$ & RA & LS \\
\hline Trichilia claussenii C.DC. & Catiguá-vermelho, quebra-machado & RA & IS \\
\hline Trichilia pallida $\mathrm{Sw}$. & Baga-de-morcego, catiguá & OC & $\mathrm{P}$ \\
\hline
\end{tabular}




\begin{tabular}{|c|c|c|c|}
\hline Monimiaceae & & & \\
\hline Mollinedia widgrenii A.DC. & Corticeira, pau-de-espeto, pimenteira & $\mathrm{OC}$ & IS \\
\hline \multicolumn{4}{|l|}{ Moraceae } \\
\hline $\begin{array}{l}\text { Sorocea bonplandii (Baill.) W.C. Burger et } \\
\text { al. }\end{array}$ & Folha-de-serra, laranjeira-do-mato & $\mathrm{OC}$ & IS \\
\hline \multicolumn{4}{|l|}{ Myrtaceae } \\
\hline Eugenia florida DC. & Guamirim, pitanga & $\mathrm{OC}$ & $\mathrm{P}$ \\
\hline \multicolumn{4}{|l|}{ Nyctaginaceae } \\
\hline Guapira opposita Vell. & $\begin{array}{l}\text { Flor-de-pérola, joão-mole, maria- } \\
\text { mole }\end{array}$ & $\mathrm{OC}$ & IS \\
\hline \multicolumn{4}{|l|}{ Ochnaceae } \\
\hline Ouratea tenuifolia Engl. & Guaratinga, guatinga & ER & IS \\
\hline \multicolumn{4}{|l|}{ Polygonaceae } \\
\hline Coccoloba mollis Casar & Falso-novateiro, folha-de-bolo & $\mathrm{OC}$ & $\mathrm{P}$ \\
\hline \multicolumn{4}{|l|}{ Primulaceae } \\
\hline Myrsine umbellata Mart. & Capororoca, capororoca-branca & FR & $\mathrm{P}$ \\
\hline \multicolumn{4}{|l|}{ Rubiaceae } \\
\hline Amaioua guianensis Aubl. & $\begin{array}{l}\text { Canela-de-veado, marmelada-brava, } \\
\text { pimentão-bravo }\end{array}$ & FR & IS \\
\hline Faramea hyacinthina Mart. & $\begin{array}{l}\text { Limãozinho-bravo, marmelada-de- } \\
\text { cachorro }\end{array}$ & $\mathrm{OC}$ & IS \\
\hline Ixora brevifolia Benth. & Ixóra-arbórea & FR & IS \\
\hline Psychotria carthagenensis Jacq. & $\begin{array}{l}\text { Carne-de-vaca, erva-de-rato-branca, } \\
\text { rainha }\end{array}$ & FR & IS \\
\hline \multicolumn{4}{|l|}{ Rutaceae } \\
\hline Galipea jasminiflora (A. St.-Hil.) Engl. & $\begin{array}{l}\text { Jasmim-do-mato, mamoninha, quina- } \\
\text { de-três-folhas }\end{array}$ & FR & IS \\
\hline Metrodorea stipularis Mart. & $\begin{array}{l}\text { Laranjeira-do-mato, limoeiro-do- } \\
\text { mato }\end{array}$ & $\mathrm{OC}$ & IS \\
\hline \multicolumn{4}{|l|}{ Salicaceae } \\
\hline Casearia decandra Jacq. & $\begin{array}{l}\text { Café-do-mato, chá-de-bugre, } \\
\text { guaçatonga, pau-de-espeto, pau-vidro }\end{array}$ & $\mathrm{OC}$ & $\mathrm{P}$ \\
\hline \multicolumn{4}{|l|}{ Solanaceae } \\
\hline Solanum rugosum Dunal & Jurubeba-do-mato & ER & IS \\
\hline \multicolumn{4}{|l|}{ Urticaceae } \\
\hline Cecropia pachystachya Trécul & Árvore-da-preguiça, embaúba & $\mathrm{CO}$ & $\mathrm{P}$ \\
\hline \multicolumn{4}{|l|}{ Vochysiaceae } \\
\hline Qualea dichotoma (Mart.) Warm. & Pau-terra e pau-terra-da-areia & $\mathrm{CO}$ & IS \\
\hline Qualea multiflora var. pubescens Mart. & Pau-de-tucano, pau-terra-do-campo & FR & $\mathrm{P}$ \\
\hline Qualea parviflora Mart. & $\begin{array}{l}\text { Pau-terra-de-flor-miúda, pau-terra- } \\
\text { mirim }\end{array}$ & $\mathrm{OC}$ & $\mathrm{P}$ \\
\hline Vochysia tucanorum Mart. & Amarelinho, pau-de-tucano, pau-doce & $\mathrm{CO}$ & $\mathrm{P}$ \\
\hline
\end{tabular}

Using the classification of successional categories, by Oliveira Filho et al. (2008a; $2008 \mathrm{~b} ; 2008 \mathrm{c} ; 2008 \mathrm{~d} ; 2008 \mathrm{e}$ ), of Minas Gerais forest inventory we found that of the 46 species identified (Table 1), $21(45.6 \%)$ are initial secondary, $20(43.5 \%)$ are pioneers, 4 $(8.7 \%)$ are late secondary and one $(2.2 \%)$ is climax.

As for the conservation status (Table 1), 4 (8.7\%) species are abundant, 5 (10.9\%) are common, $11(23.9 \%)$ are frequent, $15(32.6 \%)$ are occasional, $5(10.9 \%)$ are rare, 2 $(4.3 \%)$ are very rare and $4(8.7 \%)$ are extremely rare (Oliveira Filho et al., 2008a; 2008b; 2008c; 2008d; 2008e). The Parque da Cascata houses species of extremely rare occurrence (Guatteria ferruginea, Cariniana estrellensis, Ouratea tenuifolia and Solanum rugosum), very rare occurrence (Miconia chamissois and Cabralea canjerana) 
and rare occurrence (Platycyanus regnelli, Nectandra megapotamica, Ocotea velutina, Guarea guidonia and Trichilia claussenii), and this indicates special attention to the development of conservation and management strategies.

Of the 46 species identified, 14 (30.4\%) are endemic to Brazil: Annona sylvatica (Lobão, 2015), Casearia decandra (Marquete, 2016), Celtis pubescens (Santos, 2014), Eugenia florida (Sobral, 2014), Galipea jasminiflora (Pirani, 2011a), Guatteria ferruginea (Lobão, 2016), Jacaranda macrantha (Lohmann, 2015), Metrodorea stipularis (Pirani, 2011b), Mollinedia widgrenii (Peixoto, 2014), Ocotea velutina (Quinet, 2014), Platycyamus regnelli (Moura, 2016), Psychotria carthagenensis (Zappi, 2014), Qualea dichotoma (Souza, 2014) and Trichilia claussenii (Stefano, 2012), and occur mainly in phytogeographical areas of the Atlantic Forest and Cerrado.

Table 2 shows the horizontal phytosociological parameters for the inventoried species. Among the 46 species identified, 35 are suitable for reforestation, restoration and consolidation of degraded areas, because they present rapid growth, are pioneering or produce fruits eaten by animals (Lorenzi, 2008; 2009a; 2009b).

Table 2. Abundance values (Ni), Relative Density (RD), Relative Frequency (RF), Relative

Dominance (RDom) and Importance Value (IV) for the inventoried species

\begin{tabular}{|c|c|c|c|c|c|c|}
\hline Code & Scientific Name & $\mathbf{N i}$ & $\begin{array}{l}\text { RD } \\
(\%)\end{array}$ & $\begin{array}{l}\text { RF } \\
(\%)\end{array}$ & $\begin{array}{c}\text { RDom } \\
(\%)\end{array}$ & IV \\
\hline 21 & Ixora brevifolia Benth. & 45 & 19.15 & 8 & 20.52 & 47.67 \\
\hline 39 & Gymnanthes klotzschiana Müll.Arg. & 26 & 11.06 & 9.6 & 4.06 & 24.73 \\
\hline 17 & Galipea jasminiflora (A.St.-Hil) Engl. & 32 & 13.62 & 4.8 & 3.86 & 22.28 \\
\hline 25 & Metrodorea stipularis Mart. & 18 & 7.66 & 4 & 8.48 & 20.14 \\
\hline 1 & Alchornea glandulosa Poepp. & 14 & 5.96 & 6.4 & 4.45 & 16.81 \\
\hline 12 & Copaifera langsdorffii Desf. & 5 & 2.13 & 3.2 & 11.31 & 16.64 \\
\hline 32 & Plathymenia reticulata Benth. & 4 & 1.70 & 3.2 & 6.88 & 11.78 \\
\hline 2 & Amaioua guianensis Aubl. & 8 & 3.40 & 2.4 & 1.38 & 7.18 \\
\hline 14 & Cryptyocharya aschersoniana $\mathrm{Mez}$ & 3 & 1.28 & 2.4 & 2.40 & 6.07 \\
\hline 7 & Cariniana estrellensis (Raddi) Kuntze & 3 & 1.28 & 0.8 & 3.73 & 5.80 \\
\hline 19 & Guarea guidonia (L.) Sleumer & 4 & 1.70 & 3.2 & 0.53 & 5.43 \\
\hline 28 & Nectandra megapotamica (Spreng) Mez. & 3 & 1.28 & 2.4 & 1.03 & 4.70 \\
\hline 36 & Qualea multiflora var. pubescens Mart. & 2 & 0.85 & 1.6 & 2.20 & 4.65 \\
\hline 30 & Ocotea velutina (Nees) Rohwer & 2 & 0.85 & 1.6 & 2.05 & 4.50 \\
\hline 20 & Guatteria ferruginea A.St.-Hil. & 2 & 0.85 & 1.6 & 1.92 & 4.37 \\
\hline 22 & Jacaranda macrantha Cham. & 3 & 1.28 & 2.4 & 0.43 & 4.11 \\
\hline 15 & Eugenia florida DC. & 4 & 1.70 & 0.8 & 1.49 & 3.99 \\
\hline 33 & Platycyamus regnelli Benth. & 1 & 0.43 & 0.8 & 2.47 & 3.69 \\
\hline 23 & Jacaratia spinosa (Aubl.) A.DC. & 1 & 0.43 & 0.8 & 2.46 & 3.68 \\
\hline 9 & Cecropia pachystachya Trécul. & 3 & 1.28 & 1.6 & 0.63 & 3.51 \\
\hline 29 & Ocotea corymbosa (Meisn.) Mez. & 1 & 0.43 & 0.8 & 2.27 & 3.49 \\
\hline 3 & Annona sylvatica A.St.-Hil. & 2 & 0.85 & 1.6 & 0.92 & 3.37 \\
\hline 6 & Cabralea canjerana (Vell.) Mart. & 2 & 0.85 & 0.8 & 1.48 & 3.13 \\
\hline 47 & Vochysia sp. & 1 & 0.43 & 0.8 & 1.77 & 3.00 \\
\hline 41 & Solanum rugosum Dunal & 2 & 0.85 & 1.6 & 0.25 & 2.70 \\
\hline
\end{tabular}




\begin{tabular}{|c|c|c|c|c|c|c|}
\hline 43 & Trema micrantha (L.) Blume & 3 & 1.28 & 0.8 & 0.57 & 2.65 \\
\hline 16 & Faramea hyacinthina Mart. & 2 & 0.85 & 1.6 & 0.12 & 2.58 \\
\hline 47 & Aspidosperma sp. & 2 & 0.85 & 0.8 & 0.74 & 2.39 \\
\hline 47 & Undertermined 5 & 1 & 0.43 & 0.8 & 1.00 & 2.22 \\
\hline 47 & Undertermined 2 & 1 & 0.43 & 0.8 & 0.98 & 2.20 \\
\hline 35 & Qualea dichotoma (Mart.) Warm. & 1 & 0.43 & 0.8 & 0.70 & 1.92 \\
\hline 11 & Coccoloba mollis Casar. & 1 & 0.43 & 0.8 & 0.60 & 1.82 \\
\hline 47 & Alchornea sp. & 1 & 0.43 & 0.8 & 0.57 & 1.80 \\
\hline 27 & Mollinedia widgrenii A.DC. & 1 & 0.43 & 0.8 & 0.53 & 1.76 \\
\hline 47 & Undertermined 6 & 1 & 0.43 & 0.8 & 0.51 & 1.73 \\
\hline 47 & Ouratea sp. & 1 & 0.43 & 0.8 & 0.45 & 1.68 \\
\hline 47 & Undertermined 7 & 1 & 0.43 & 0.8 & 0.41 & 1.63 \\
\hline 47 & Swartzia sp. & 1 & 0.43 & 0.8 & 0.32 & 1.55 \\
\hline 47 & Undertermined 4 & 1 & 0.43 & 0.8 & 0.28 & 1.50 \\
\hline 24 & Luehea grandiflora Mart. & 1 & 0.43 & 0.8 & 0.27 & 1.49 \\
\hline 26 & Miconia cf. chamissois Naudin & 1 & 0.43 & 0.8 & 0.26 & 1.49 \\
\hline 40 & Senna multijuga (Rich.) H.S. Irwin \& Barneby & 1 & 0.43 & 0.8 & 0.25 & 1.47 \\
\hline 47 & Croton $\mathrm{sp}$. & 1 & 0.43 & 0.8 & 0.23 & 1.45 \\
\hline 47 & Undertermined 3 & 1 & 0.43 & 0.8 & 0.22 & 1.44 \\
\hline 47 & Undertermined 8 & 1 & 0.43 & 0.8 & 0.21 & 1.43 \\
\hline 47 & Bauhinia sp. & 1 & 0.43 & 0.8 & 0.20 & 1.42 \\
\hline 47 & Jacaranda sp. & 1 & 0.43 & 0.8 & 0.19 & 1.42 \\
\hline 10 & Celtis pubescens Spreng. & 1 & 0.43 & 0.8 & 0.19 & 1.41 \\
\hline 46 & Vochysia tucanorum Mart. & 1 & 0.43 & 0.8 & 0.15 & 1.38 \\
\hline 44 & Trichilia claussenii C.DC. & 1 & 0.43 & 0.8 & 0.12 & 1.35 \\
\hline 47 & Undertermined 1 & 1 & 0.43 & 0.8 & 0.12 & 1.34 \\
\hline 18 & Guapira opposita Vell. & 1 & 0.43 & 0.8 & 0.09 & 1.32 \\
\hline 47 & Myrcia sp. & 1 & 0.43 & 0.8 & 0.08 & 1.31 \\
\hline 5 & Astronium fraxinifolium Schott ex Spreng. & 1 & 0.43 & 0.8 & 0.08 & 1.30 \\
\hline 47 & Chomelia sp. & 1 & 0.43 & 0.8 & 0.08 & 1.30 \\
\hline 38 & Myrsine umbellata (Mart.) Mez & 1 & 0.43 & 0.8 & 0.07 & 1.30 \\
\hline 37 & Qualea cf. parviflora Mart. & 1 & 0.43 & 0.8 & 0.08 & 1.30 \\
\hline 4 & Aspisdosperma subincanum Mart. & 1 & 0.43 & 0.8 & 0.06 & 1.29 \\
\hline 31 & Ouratea cf. tenuifolia Engl. & 1 & 0.43 & 0.8 & 0.06 & 1.29 \\
\hline 34 & Psychotria cf. carthagenensis Jacq. & 1 & 0.43 & 0.8 & 0.06 & 1.29 \\
\hline 42 & Sorocea bonplandii (Baill.) W.C. Burger et al. & 1 & 0.43 & 0.8 & 0.04 & 1.27 \\
\hline 45 & Trichilia pallida Swartz. & 1 & 0.43 & 0.8 & 0.05 & 1.27 \\
\hline 8 & Casearia decandra Jacq. & 1 & 0.43 & 0.8 & 0.03 & 1.26 \\
\hline 13 & Croton urucurana Baill. & 1 & 0.43 & 0.8 & 0.04 & 1.26 \\
\hline 47 & Daphnopsis sp. & 1 & 0.43 & 0.8 & 0.04 & 1.26 \\
\hline
\end{tabular}




\section{Species with higher IV}

The species with the highest importance values (IV) (Table 2) were Ixora brevifolia (47.67), Gymnanthes klotzschiana (= Sebastiania commersoniana (Baill) L.B. Sm. \& Downs (Oliveira, 2014)) (24.73), Galipea jasminiflora (22.28), Metrodorea stipularis (20.14), Alchornea glandulosa (16.81) and Copaifera langsdorffii Desf. (16.64). The abundance of these species, totaling 160 individuals, represent $68 \%$ of the sampled individuals.

Relating these species with other surveys in the same typology, Machado et al. (2004) inventoried a fragment of seasonal forest near a pond in Lavras, Minas Gerais, Brazil, in an area of Atlantic Forest, with Köppen Cwa climate, on nitosoils and argisoils, and found only one individual of S. commersoniana, and many G. jasminiflora. Rocha et al. (2005) inventoried a swamp forest on cambisoils and argisoils in Coqueiral, Minas Gerais, Brazil, less than $50 \mathrm{~km}$ from Lavras, in the transition of the Cerrado to the Atlantic Forest area, and found that G. jasminiflora, S. commersoniana and $M$. stipularis had the highest IV, and occupied mainly the hillside areas.

Meira-Neto and Martins (2002), inventorying a fragment from natural regeneration, about 60 years old in the municipality of Viçosa, Zona da Mata, Minas Gerais, in an Atlantic Forest area, with Aw climate, did not obtain registration of any of the species with the highest abundance in this present survey.

In surveys of shrubby tree flora, even in similar environments, there are low floristic similarities, indicating that there are other large-scale conditionings interfering with the distribution of the species.

Regarding some features of the most expressive species, I. brevifolia is considered late secondary, and exclusive to semi-deciduous forest of altitude, occurring mainly in well-drained and medium fertility terrain (Prado Júnior et al., 2012).

$S$. commersoniana is classified as a pioneer species, deciduous with autochoric dispersion (Cappelatti and Schmitt, 2009) and occurs almost exclusively in humid areas, in riparian forests and flooded forests (Barddal et al., 2004; Kanieski, 2013). It is usually found in groups, reaching pure populations, developing in fields and on the border of clumps; it is rare within dense primary forest (Lorenzi, 2008). In the alluvial plain of the Paraiba River in São José dos Campos, São Paulo, Brazil, $S$. commersoniana presented the second highest IV, occurring in the dominant stratum in both the canopy and the understory (D'Orazio and Catharino, 2013). The Sebastiania genus includes species considered exclusively of marsh, such as: $S$. brasiliensis Spreng, S. edwalliana Pax \& K. Hoffm., S. klotzschiana (Müll. Arg.) Müll. Arg. (Torres et al. 1992) and S. serrata (Baill. ex Müll. Arg.) Müll. Arg. (Ivanauskas et al., 1997).

Regarding soil conditions, $S$. commersoniana occurred mostly in neosoils (Botrel et al., 2002), indicating a preference for soils with higher sand content (Kolb et al., 1998). According to Callegaro (2012), the presence of this species may be related to the secondary stage of forest succession, being an indicator species of this stage in a mixed broadleaf forest stretch, classifying it as a pioneer species (Longhi-Santos, 2013).

G. jasminiflora is an early secondary species (Oliveira Filho et al., 2008d), endemic to Brazil, which occurs in phytogeographical areas of Cerrado and Atlantic Forest, in the vegetation of semideciduous forest (Pirani, 2011a). This 
species showed preference for dry soil, occurring at low densities in swamp forest (Teixeira and Assis, 2003).

Both M. stipularis and G. jasminiflora are early secondary species (Oliveira Filho et al., 2008d), occur mainly within the dense forest and are less frequent in open and secondary formations, with very low population density (Lorenzi, 2008). $M$. stipularis can be found in the phytogeographic areas of Cerrado and Atlantic Forest in the vegetation of semideciduous forest (Pirani, 2011b).

A. glandulosa is a pioneer species (Oliveira Filho et al., 2008d), which may appear in swamps, but occurs mainly in areas with temporary waterlogging, such as ciliary or riparian and gallery forests, and even drier forests, where waterlogged soil never occurs. It can be found in Cerrado (lato sensu) vegetation, riparian or gallery forest, rain forest and restinga (sandbank vegetation) (Paula-Souza, 2014).

C. langsdorffii is a pioneer species (Oliveira Filho et al., 2008e), characteristic of Cerrado transition to broadleaf semideciduous forest formations, occurring in secondary formations and in dense primary forests (Lorenzi, 2008). According to Oliveira Filho and Ratter (2001), C. langsdorffii is a habitat generalist, and, in general, is dominant in the face of most of the remaining forests in the Central South of the state of Minas Gerais.

\section{Relationship of species and the environment}

The correlations between the physical medium parameters, hydrography, topography ("Appendix Table 1"), granulometry and soil fertility parameters ("Appendix Tables 2 and 3") are in "Appendix Tables 4, 5 and 6" considering the 12 points and the three soil sampling depths. Via quantification of sand, silt and clay levels, the soil textural classes ranged from franco silty-clayey to silty-clayey. The relief is predominantly wavy, especially the aspect to the southwest.

Twenty-nine significant correlations greater than or equal to 0.70 in the $0-10 \mathrm{~cm}$ layer, 62 correlations in the 10 to $20 \mathrm{~cm}$ layer, and 46 at 20 in the $30 \mathrm{~cm}$ layer were found. The smaller amount of correlations in the topsoil may be due to the contribution of nutrient cycling by litter deposition, which is the layer least dependent on the source material.

In the canonical correlation between fertility and particle size parameters (Fig. 2 ), we found positive associations among fine sand, micro-pores, particle density and silt levels with $\mathrm{Mg}, \mathrm{Ca}, \mathrm{SB}, \mathrm{V}, \mathrm{Zn}, \mathrm{Fe}, \mathrm{Mn}, \mathrm{Cu}$, and $\mathrm{P}$. In the opposite direction, there are positive associations among coarse sand, clay and macro-pores with $\mathrm{H}+$ $\mathrm{Al}, \mathrm{K}, \mathrm{Al}$, and Aluminum Saturation. The $\mathrm{pH}, \mathrm{CEC}$ and organic matter did not show associations with other parameters, both in magnitude and in direction. 


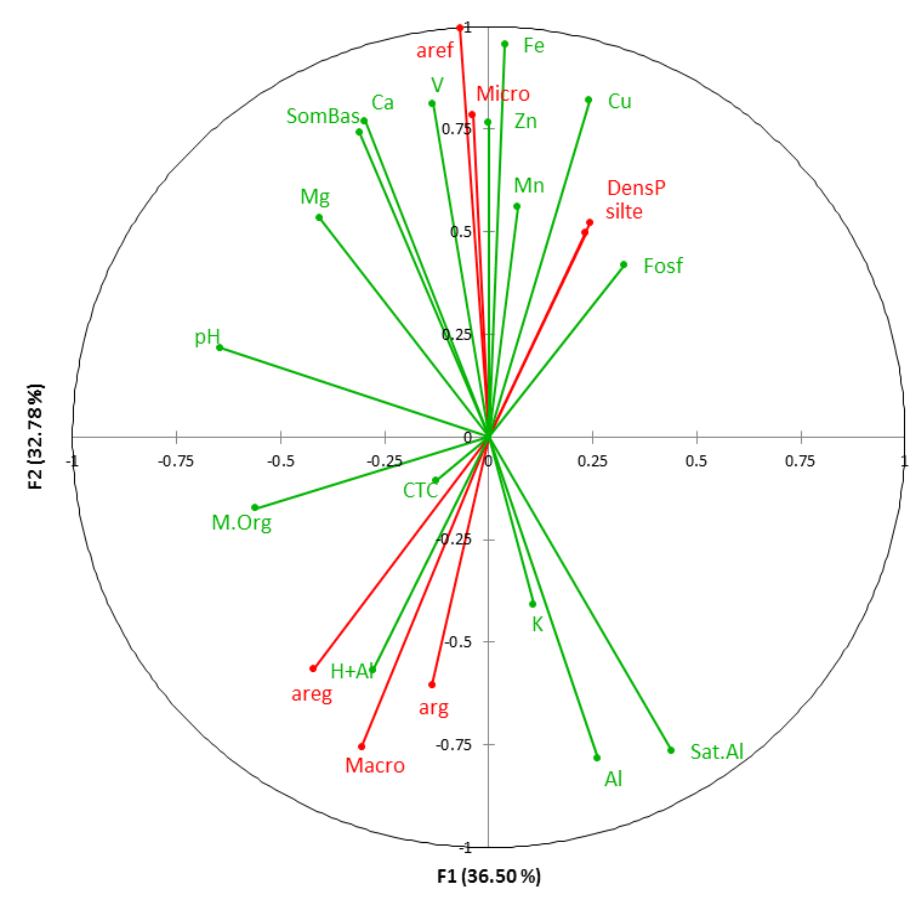

Figure 2. Canonical correlation among particle size and fertility parameters for the soil depth up to $30 \mathrm{~cm}$ (average levels)

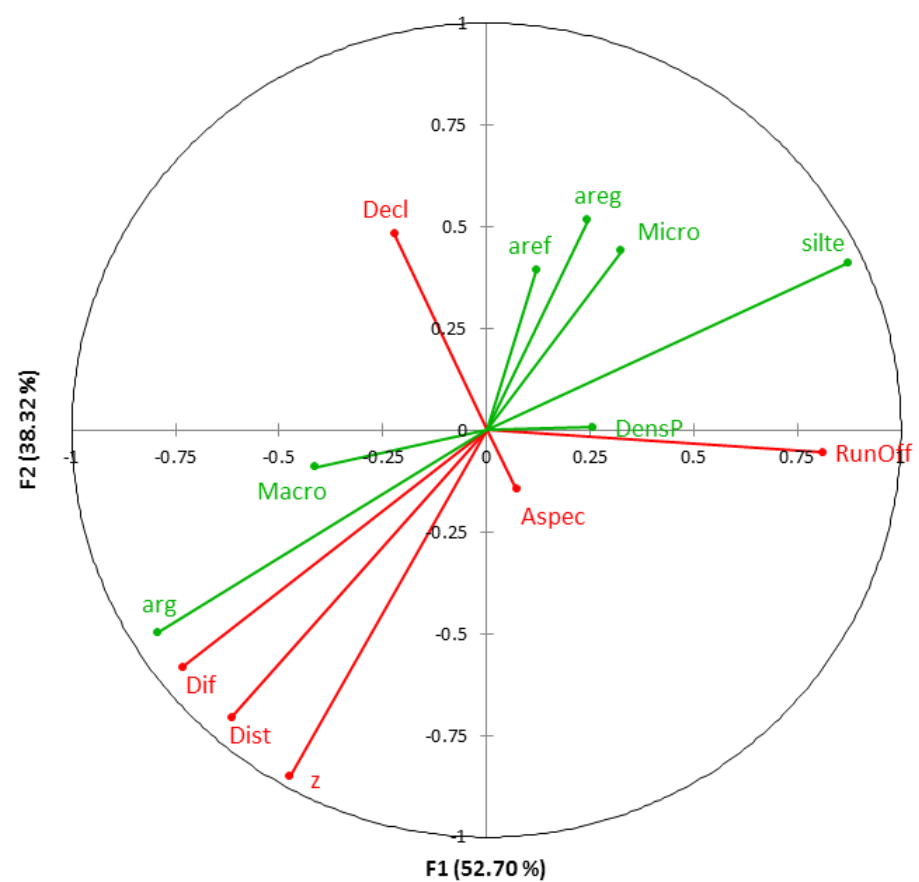

Figure 3. Canonical correlation among parameters particle size, topography, altitude difference and distance from the water body, for the soil depth up to $30 \mathrm{~cm}$ (average levels) 
In the canonical correlation among particle size, relief and hydrographic parameters in Fig. 3, it is observed that the difference in altitude and the distance from the water body are positively correlated, and validate the negative correlation with runoff. It was found that, with increasing distance from the stream, the clay content and the amount of macro-pores increase, hence silt, sand and micro-pore content reduce.

Thus, a negative correlation between micro-pores and clay occurred. We expected the opposite effect, increasing the amount of micro-pores and reducing macro-pores with stream clearance and increase in clay content, since the function of the macropores is to facilitate aeration and water infiltration into the soil, and the function of micro-pores is retaining water. The aspect and slope were not associated with the soil particle size.

In the relationship of species of higher IV to physical parameters by principal components (Fig. 4), related to altitude difference and distance from the water body, runoff, aspect, slope and dendrometric parameters (height and sectional area), we found two species. They showed greater preference for river proximity: Alchornea glandulosa (1) and Gymnanthes klotzschiana (39), with few individuals of species 39 away from the stream, showing tolerance to well-drained sites. In addition to these species, some Ixora brevifolia (21) and Galipea jasminiflora individuals (17) occurred in areas with increased runoff and nearby water, which shows tolerance of these species to poorly drained environments.

An uncontrolling source interfering in the distribution of species is seed dispersal, which may be adding a contribution to the aggregation of individuals, inherent in a larger-scale approach, it not being possible to isolate this effect. Alchornea glandulosa and Ixora brevifolia have zoochory mainly by avifauna (Pascotto, 2006; Prado Júnior et al., 2012), with less chance of this effect, but Gymnanthes klotzschiana, Galipea jasminiflora and Metrodorea stipularis have autochoric dispersion (Cosmo et al., 2010; Piedade, 1991), with a greater chance of aggregation in the plant community.

The size of the trees did not show a strong negative correlation with increasing steepness, and no significant negative correlation with the faces turned mainly to the north, but the direction of the vectors showed this trend. The tallest species and with more sectional area were Ixora brevifolia and Metrodorea stipularis.

A feature of the analyzed environment is its face, mainly on the southwest. The species with greater abundance also occurred on the southeast and south faces, but with greater overlap on the southwest face, indicating that they prefer less exposure to sunlight throughout the year.

The difference in altitude and distance from the water body indicated the species Alchornea glandulosa and Sebastiania commersoniana as having lower dispersion, being closer to the water body and at different altitudes. The species with greater occurrence and farther from the water body was Metrodorea stipularis.

Interestingly, Alchornea glandulosa had the lowest amount of runoff, indicating it does tolerat places with greater drainage and/or tendency to waterlog, contrary to information found in the literature. An assumption for this may be in the $12.5 \times 12.5 \mathrm{~m}$ resolution of the digital elevation model, and the distance of trees to the quadrant point, selecting cells (pixels) with lower runoff adjacent to the cells containing the tree position in the ground.

In preference in relation to the slope, the species that occupied sites with greater steepness was Achornea glandulosa, and among the other species, there were no large variations as to slope preference. 


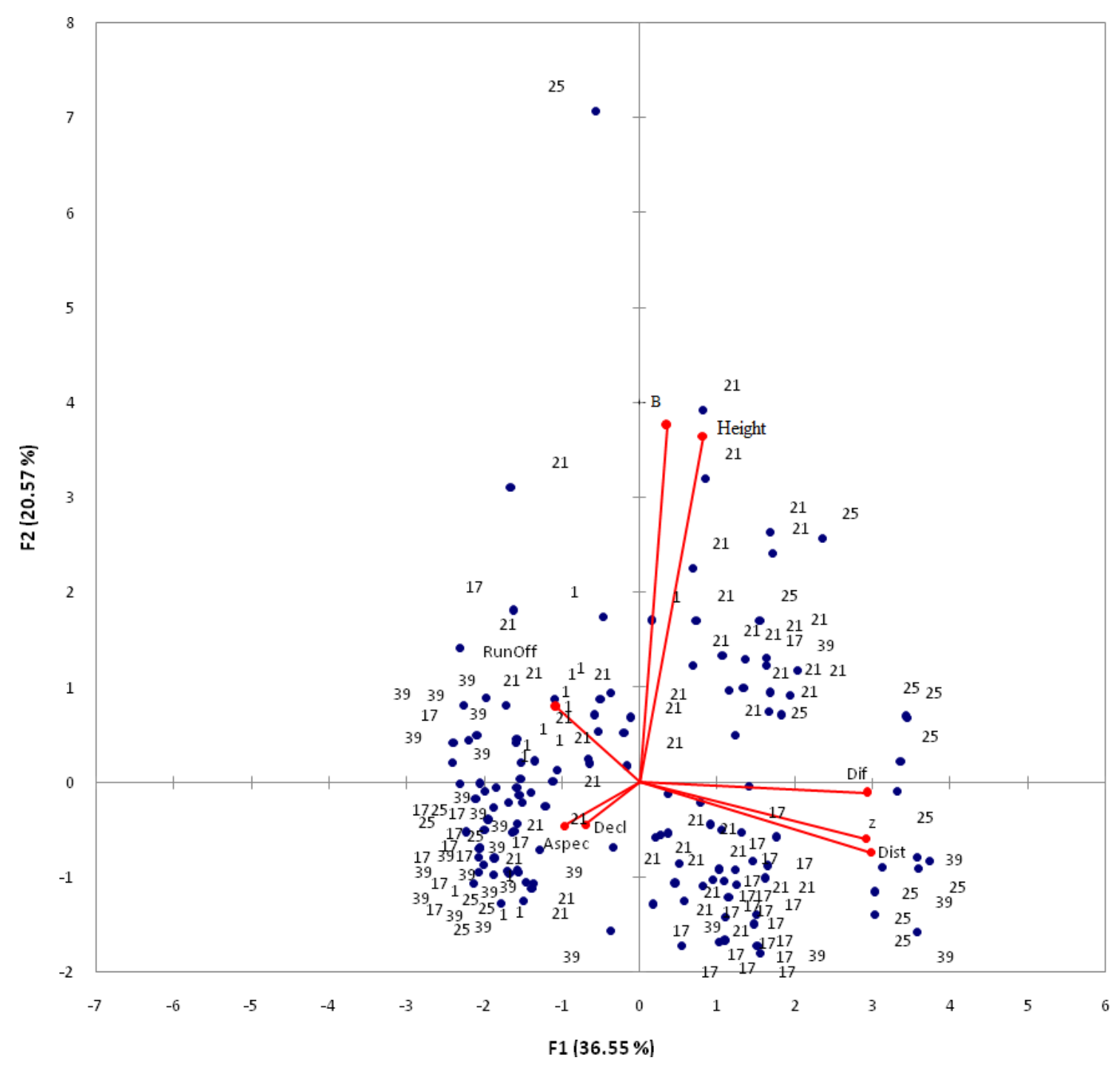

Figure 4. Analysis of major components of physical parameters (distance and altitude difference of the water body, slope, aspect) and tree size (basal area and height) for the species with the highest importance value

Continuing with we discuss relationships between particle size parameters associated to topography and water features and also identify relationships between fertility parameters and particle size parameters.

For Alchornea glandulosa and Gymnanthes klotzschiana species, which prefer the shortest distance from the stream and less difference in altitude, we can expect small differences in clay, silt and sand content, reducing the percentage of clay and increasing silt and sand. In these environments, particle densities and micro-porosity will be greater, following the trends in figure 3. Continuing the correlations, for fertility, Al contents are lower, and $\mathrm{Ca}, \mathrm{Mg}, \mathrm{P}, \mathrm{SB}, \mathrm{V}, \mathrm{Cu}, \mathrm{Zn}, \mathrm{Fe}$ and $\mathrm{Mn}$ contents are higher, although all $\mathrm{Fe}$ and $\mathrm{Mn}$ levels in the samples are above the need of the plants.

In all samples, the micro and macro-porosity are high, but not enough to retain water by surface tension forces, and particle density indicates higher organic matter content. 
Acidity is low, the $\mathrm{Ca}$ content is high, the $\mathrm{Mg}$ content is moderate and the $\mathrm{P}$ content is low. $\mathrm{Zn}$ and $\mathrm{Cu}$ have high values and base saturation is high.

After the analysis, it follows that for degraded environments with similar topographical, hydrological and soil conditions, colonization would start by including these major species, all of them initial secondary, except Alchornea, which is pioneer. That is, all have requirements to start the ecological succession, theoretically heliophytic species in their early development. Achornea and Gymnanthes could be planted closer to the stream, Galipea and Ixora could mainly occupy the middle range, and Metrodorea would be planted farther from the stream, based on the analyses presented.

\section{Conclusion}

Ecological restoration processes and recovery of degraded areas go through issues such as indication of native species, which require well-founded forest inventories, within the floristic, phytosociology, ecophysiology, and even faunal relationships.

The results in this study demonstrate a relationship between biotic and abiotic factors of the area, and confirm the influence of the stream that flows through the fragment on the vegetation, determining species occurrence and distribution. To validate the indication of species to compose ecological restoration proposed in this work, an assay with long-term monitoring is necessary.

Acknowledgments. To employees of the SELTUR (Sete Lagoas, Leisure and Tourism S/A (Lazer e Turismo S/A)) that worked on Parque Municipal da Cascata in the period; to ADESA NGO, for the field support, especially Gustavo Ganzaroli Mahé; to Embrapa Maize and Sorghum, for the laboratory analysis; and to our friends from the UNIFEEM course who helped in the fieldwork: Gabriel Avelar Miranda, Lidiane Martinho Tarabal, Pedro Henrique Ferreira Gomes, Gleyce Aparecida dos Santos, Jairo Alexandre Moreira, Leandro Vasconcelos F. Tavares, Jordane Felizardo de Matos, Estefânia Sue Ellen S. Sousa, Brenda Suellen M. de Souza, Octávio Gabryel Araujo, Michel Anderson Silva Lourenço, Douglas Michel Costa Souza, Kênia Grasielle de Oliveira, Daniel Braga Valaci Pontes Ferrari, Ana Luiza Gangana, Luana Patrícia Santana Pereira de Sousa, Thiago Pessoa Teixeira.

\section{REFERENCES}

[1] ADESA - Associação de Desenvolvimento Ambiental (2007): Parque da Cascata - Serra Santa Helena. https://posuta.com/pt/sete-lagoas/organizacao-nao-governamentalong/adesa-associacao-de-desenvolvimento-ambiental/. (Accessed: 28 Apr 2010).

[2] Almeida, N. O. (2004): Implantação de matas ciliares por plantio direto utilizando-se sementes peletizadas. - Lavras, MG: Universidade Federal de Lavras 269 p. Thesis.

[3] Aquino, C. (2006): Avaliação de três formas de enriquecimento em área ciliar revegetada junto ao Rio Mogi-Guaçu, SP. - Rio Claro, SP: Universidade Estadual Paulista "Júlio de Mesquita Filho" 154 p. Thesis.

[4] Araújo, G. M., Guimarães, A. J. M., Nakajima, J. N. (1997): Fitossociologia de um remanescente de mata mesófila semidecídua urbana, Bosque John Kennedy, Araguari, MG, Brasil - Revista Brasileira de Botânica 20(1): 67-77.

[5] Araújo, G. M., Haridasan, M. (1997): Estrutura fitossociológica de duas matas mesófitas semidecíduas, em Uberlândia, Triângulo Mineiro. - Naturalia 22: 115-129.

[6] Barbosa, L. M., Asperti, L. M., Bedinelli, C., Barbosa, J. M., Zeigler, T. I. (1992): Estudos sobre o estabelecimento e desenvolvimento de espécies com ampla ocorrência em mata ciliar. - Revista do Instituto Florestal 4: 605-608. 
[7] Barbosa, L.M., Lieberg, S. A. (1998): Proposta metodológica de enriquecimento florístico no parque Ecológico do Guarapiranga - SP. - In Anais do Simpósio de Ecossistemas Brasileiros 4: 250-256. (In Brazil)

[8] Barddal, M. L., Roderjan, C. V., Galvão, F., Curcio, G. R. (2004): Fitossociologia do subbosque de uma Floresta Ombrófila Mista Aluvial, no Município de Araucária, PR. Ciência Floresta 41(1): 35-45.

[9] Botrel, R. T., Oliveira Filho, A., Rodrigues, L. A., Curi, N. (2002): Influência do solo e topografia sobre as variações da composição florística e estrutura da comunidade arbóreoarbustiva de uma floresta estacional semidecidual em Ingaí, MG. - Revista Brasileira de Botânica 25(2): 195-213.

[10] Callegaro, R. M. (2012): Variações florísticas e estruturais de um remanescente de Floresta Ombrófila Mista Montana em Nova Prata- RS. - Santa Maria, RS: Universidade Federal de Santa Maria 96 p. Thesis.

[11] Cappelatti, L., Schmitt, J. L. (2009): Caracterização da flora arbórea de um fragmento urbano de Floresta Estacional Semidecidual no Rio Grande do Sul, Brasil. - Pesquisas, Botânica 60: 341-354.

[12] Carvalho, D. A., Oliveira-Filho, A. T., Van Den Berg, E., Fontes, M. A. L., Vilela, E. A., Marques, J. J. G. S. M., Carvalho, W. A. C. (2005): Variações florísticas e estruturais do componente arbóreo de uma floresta ombrófila alto-montana às margens do Rio Grande, Bocaina de Minas, MG, Brasil. - Acta Botanica Brasilica 19(1): 91-109.

[13] Cosmo, N. L., Nogueira, A. C., Lima, J. G., Kuniyoshi, Y. S. (2010): Morfologia de fruto, semente e plântula de Sebastiania commersoniana, Euphorbiaceae. - Floresta 40(2): 419-428.

[14] Costa, A. A., Araújo, G. M. (2001): Comparação da vegetação arbórea de cerradão e de cerrado na Reserva do Panga, Uberlândia, Minas Gerais. - Acta Botanica Brasílica 15(1): 63-72.

[15] Cottam, G., Curtis, J. T. (1956): The use of distance measures in phytosociological sampling. - Ecology 37(3): 451-460.

[16] Coutinho, M. P., Martins, S. V., Barroso, D. G., Coutinho, R. P., Marciano, C. R. (2002): Sobrevivência e crescimento inicial de espécies arbóreas nativas no enriquecimento de floresta secundária em Cruzeiro, SP. - In Anais do Simpósio Nacional sobre Recuperação de Áreas Degradadas: 271-273. (In Brazil)

[17] D'Orazio, F. A. E., Catharino, E. L. M. (2013): Estrutura e florística de dois fragmentos de florestas aluviais no Vale do rio Paraíba do Sul, SP, Brasil. - Hoehnea 40(3): 567-582.

[18] Durigan, G. E., Dias, H. C. S. (1991): Abundância e diversidade da regeneração natural sob mata ciliar implantada. - In Anais do Congresso Florestal Brasileiro 6: 308-312. (In Brazil)

[19] Flora do Brasil 2020 (2016): Jardim Botânico do Rio de Janeiro. (Accessed: 28 Sept 2016) http://floradobrasil.jbrj.gov.br/.

[20] Getirana, A. (2016): Extreme water deficit in Brazil detected from space. - Journal of Hydrometeorology 17(2): 591-599.

[21] Gomide, R. L., Albuquerque, P. E. P., Andrade, C. L. T., Durães, F. O. M., Viana, J. H. M. (2006): Caracterização climática e determinação da necessidade hídrica de culturas do sítio específico de precisão de Sete Lagoas para a fenotipagem de genótipos de cereais tolerantes à seca. (Accessed: 28 Sept 2016).

http://ainfo.cnptia.embrapa.br/digital/bitstream/item/29733/1/Caracterizacaoclimatica.pdf.

[22] IBGE (2004): Mapa de biomas e de vegetação. (Accessed: 27 Sept 2016). http://www.ibge.gov.br/home/presidencia/noticias/21052004biomashtml.shtm.

[23] Ivanauskas, N. M., Rodrigues, R. R., Nave, A. G. (1997): Aspectos ecológicos de um trecho de floresta de brejo em Itatinga, SP: florística, fitossociologia e seletividade de espécies. - Revista Brasileira de Botânica 20(2): 139-153. 
[24] Kageyama, P. Y., Gandara, F. B. (2001): Recuperação de áreas ciliares. In Rodrigues, R. R., Leitão Filho, H. F. (eds). Matas ciliares: conservação e recuperação, 2nd Edition. Brazil: EDUSP, FAPESP, São Paulo. 249-269.

[25] Kanieski, M. R. (2013): Estudo dendrológico de Sebastiania commersoniana (Baill.) L.B. Sm. \& R.J. Downs e de arbóreas invasoras em Floresta Ombrófila Mista Aluvial, Sul do Brasil. - Curitiba, PR: Universidade Federal do Paraná 127 p. Thesis.

[26] Kolb, R. M., Medri, M. E., Bianchini, E., Pimenta, J. Á., Giloni, P. C., Correa, G. T. (1998): Anatomia ecológica de Sebastiania commersoniana (Baillon) Smith \& Downs (Euphorbiaceae) submetida ao alagamento. - Revista Brasileira de Botânica 21(3): 305312.

[27] Lobão, A.Q. (2015): Flora do Brasil 2020. Jardim Botânico do Rio de Janeiro. Annona. http://reflora.jbrj.gov.br/reflora/floradobrasil/FB110263. (Accessed: 28 Sept 2016)

[28] Lobão, A.Q. (2015): Flora do Brasil 2020. Jardim Botânico do Rio de Janeiro. Guatteria. http://reflora.jbrj.gov.br/reflora/floradobrasil/FB110397. (Accessed: 29 Sept 2016)

[29] Lohmann, L. G. (2015): Flora do Brasil 2020. Jardim Botânico do Rio de Janeiro. Jacaranda. http://reflora.jbrj.gov.br/reflora/floradobrasil/FB114150. (Accessed: 29 Sept 2016)

[30] Longhi-Santos, T. (2013): Dendroecologia de Sebastiania commersoniana (Baill.) L.B.Sm. \& Downs em um fragmento de Floresta Ombrófila Mista Aluvial, Paraná, Brasil. - Curitiba, PR. Universidade Federal do Paraná 95 p. Thesis,

[31] Lopes, A. S., Guilherme, L. R. G. (2004). Interpretação de análise de solo: conceitos e aplicações. Boletim técnico 2. Brazil: ANDA, Lavras 49 p.

[32] Lorenzi, H. (2008): Árvores brasileiras: manual de identificação e cultivo de plantas arbóreas nativas do Brasil, v. 1, 5th Edition. - Brazil: Instituto Plantarum, Nova Odessa $384 \mathrm{p}$.

[33] Lorenzi, H. (2009a): Árvores brasileiras: manual de identificação e cultivo de plantas arbóreas nativas do Brasil, v. 2, 3rd. Edition. - Brazil: Instituto Plantarum, Nova Odessa $384 \mathrm{p}$.

[34] Lorenzi, H. (2009b): Árvores brasileiras: manual de identificação e cultivo de plantas arbóreas nativas do Brasil, v. 3. Brazil: Instituto Plantarum, Nova Odessa 384 p.

[35] Machado, E. L. M., Oliveira-Filho, A. T., Carvalho, W. A. C., Souza, J. S., Borém, R. A. T., Botezelli, L. (2004): Análise comparativa da estrutura e flora do compartimento arbóreo-arbustivo de um remanescente florestal na Fazenda Beira Lago, Lavras, MG. Revista Árvore 28(4): 499-516.

[36] Mahé, G. G. (2009): Restauração nucleadora para formação de corredores ecológicos no Parque da Cascata, Sete Lagoas - MG. - Belo Horizonte, MG: Centro Universitário de Belo Horizonte. Monograph.

[37] Marquete, R. (2016): Flora do Brasil 2020. Jardim Botânico do Rio de Janeiro. Salicaceae. http://reflora.jbrj.gov.br/reflora/floradobrasil/FB14367. (Accessed: 28 Sept 2016)

[38] Meira-Neto, J. A. A., Martins, F. R. (2002): Composição florística de uma Floresta Estacional Semidecidual Montana no Município de Viçosa-MG. - Revista Árvore 26(4): 437-446.

[39] Moura, T. M. (2016): Flora do Brasil 2020. Jardim Botânico do Rio de Janeiro. Platycyamus. http://reflora.jbrj.gov.br/reflora/floradobrasil/FB29815. (Accessed: 29 Sept. 2016)

[40] Oliveira Filho, A. T., Ratter, J. A. (2001): Padrões florísticos das matas ciliares da região do cerrado e a evolução das paisagens do Brasil Central durante o Quaternário Tardio. In: Oliveira Filho, A. T., Scolforo, J. R. (eds). Inventário florestal de Minas Gerais: espécies arbóreas da flora nativa. Brazil: UFLA, Lavras. 73-89.

[41] Oliveira Filho, A. T., Scolforo, J. R., Silva, C. P. C. (2008a). Compilação e caracterização das espécies arbóreas da flora nativa de Minas Gerais. In Oliveira Filho, A. T., Scolforo, 
J. R. (eds). Inventário florestal de Minas Gerais: espécies arbóreas da flora nativa. Brazil: UFLA, Lavras. 1-8.

[42] Oliveira Filho, A. T., Van Den Beg, E., Machado, E. L. M., Pifano, D. S., Santos, R. M., Valente, A. S. M., Martins, J. C., Silva, C. P. C. (2008c). Espécies de ocorrência exclusiva do domínio do cerrado. In Oliveira Filho, A. T., Scolforo, J. R. (eds). Inventário florestal de Minas Gerais: espécies arbóreas da flora nativa. Brazil: UFLA, Lavras. 157208.

[43] Oliveira Filho, A. T., Van Den Beg, E, Martins, J. C., Valente, A. S. M., Pifano, D. S., Santos, R. M., Machado, E. L. M., Silva, C. P. C. (2008e). Espécies de ocorrência do domínio atlântico, do cerrado e da caatinga. In: Oliveira Filho, A. T., Scolforo, J. R. (eds). Inventário florestal de Minas Gerais: espécies arbóreas da flora nativa. Brazil: UFLA, Lavras. 421-539.

[44] Oliveira Filho, A. T., Van Den Beg, E., Sobral, M. E. G., Pifano, D. S., Machado, E. L. M., Santos, R. M., Martins, J. C., Valente, A. S. M., Silva, A. C., Higuchi, P., Silva, C. P. C. (2008b). Espécies de ocorrência exclusiva do domínio atlântico. In: Oliveira Filho, A. T., Scolforo, J. R. (eds). Inventário florestal de Minas Gerais: espécies arbóreas da flora nativa. Brazil: UFLA, Lavras. 11-54.

[45] Oliveira Filho, A. T., Van Den Beg, E., Sobral, M. E. G., Pifano, D. S., Santos, R. M., Valente, A. S. M., Machado, E. L. M., Martins, J. C., Silva, C. P. C. (2008d). Espécies de ocorrência do domínio atlântico e do cerrado. In: Oliveira Filho, A. T., Scolforo, J. R. (eds). Inventário florestal de Minas Gerais: espécies arbóreas da flora nativa. Brazil: UFLA, Lavras. 217-418.

[46] Oliveira Filho, A. T., Vilela, E. A., Carvalho, D. A., Gavilanes, M. L. (1994): Effects of soil and topography on the distribution of tree species in a tropical riverine forest in southeastern Brazil. - Journal of Tropical Ecology 10(4): 483-508.

[47] Oliveira, L.D.S.D. (2014): Flora do Brasil 2020. Jardim Botânico do Rio de Janeiro. Gymnanthes. http://reflora.jbrj.gov.br/reflora/floradobrasil/FB55510. (Accessed: 29 Sept 2016)

[48] Palmer, M. A., Ambrose, R. F., Poff, N. L. (1997): Ecological theory and community restoration. Restoration Ecology 5(4): 291-300.

[49] Pascotto, M. C. (2006): Avifauna dispersora de sementes de Alchornea glandulosa (Euphorbiaceae) em uma área de mata ciliar no Estado de São Paulo. - Revista Brasileira de Ornitologia 14(3): 291-296.

[50] Peixoto, A. L. (2014): Flora do Brasil 2020. Jardim Botânico do Rio de Janeiro. Monimiaceae. http://reflora.jbrj.gov.br/reflora/floradobrasil/FB10106. (Accessed: 29 Sept 2016)

[51] Pereira-Silva, E. F. L., Santos, J. E., Kageyama, P. Y., Hardt, E. (2004): Florística e fitossociologia dos estratos arbustivo e arbóreo de um remanescente de cerradão em uma unidade de conservação do Estado de São Paulo. - Revista Brasileira de Botânica 27(3): 533-544.

[52] Piedade, L. H. (1991): Biologia floral e reprodutiva de Galipea jasminiflora Engler (Rutaceae). Brazil: UNICAMP, Campinas 99 p.

[53] Pirani, J. R. (2011a): Flora do Brasil 2020. Jardim Botânico do Rio de Janeiro. Rutaceae. http://reflora.jbrj.gov.br/reflora/floradobrasil/FB746. (Accessed: 28 Sept 2016)

[54] Pirani, J. R. (2011b): Flora do Brasil 2020. Jardim Botânico do Rio de Janeiro. Rutaceae. http://reflora.jbrj.gov.br/reflora/floradobrasil/FB823. (Accessed: 29 Sept 2016)

[55] Prado Júnior, J. A., Faria Lopes, S., Schiavini, I., Vale, V. S., Oliveira, A. P., Gusson, A. E., Dias Neto, O. C., Stein, M. (2012): Fitossociologia, caracterização sucessional e síndromes de dispersão da comunidade arbórea de remanescente urbano de Floresta Estacional Semidecidual em Monte Carmelo, Minas Gerais. - Rodriguésia 3(3): 489-499.

[56] Quinet, A. (2014): Flora do Brasil 2020. Jardim Botânico do Rio de Janeiro. Lauraceae. http://reflora.jbrj.gov.br/reflora/floradobrasil/FB8493. (Accessed: 29 Sept 2016) 
[57] Paula-Souza, J. (2014): Flora do Brasil 2020. Jardim Botânico do Rio de Janeiro. Euphorbiaceae. http://reflora.jbrj.gov.br/reflora/floradobrasil/FB17456. (Accessed: 29 Sept 2016)

[58] Rocha, C. T. V., Carvalho, D. A., Fontes, M. A. L., Oliveira-Filho, A. T., Van Den Berg, E., Marques, J. J. G. S. M. (2005): Comunidade arbórea de um continuum entre Floresta Paludosa e de Encosta em Coqueiral, Minas Gerais, Brasil. - Revista Brasileira de Botânica 28(2): 203-218.

[59] Rodrigues, R. R., Gandolfi, S. (2001). Conceitos, tendências e ações para a recuperação de florestas ciliares. In Rodrigues, R. R., Leitão Filho, H. F. (eds). Matas ciliares: conservação e recuperação, 2nd Edition. - Brazil: EDUSP, FAPESP, São Paulo. 235-247.

[60] Rodrigues, R. R., Leitão Filho, H. F. (2001): Matas ciliares: conservação e recuperação, 2nd Edition. - Brazil: EDUSP, FAPESP, São Paulo. 320 p.

[61] Santos, A.D. (2014): Flora do Brasil 2020. Jardim Botânico do Rio de Janeiro. Cannabaceae. http://reflora.jbrj.gov.br/reflora/floradobrasil/FB32981. (Accessed: 28 Sept 2016)

[62] Silva, N. R. S., Martins, S. V., Meira Neto, J. A. A., Souza, A. L. (2004): Composição florística e estrutura de uma floresta estacional semidecidual montana em Viçosa, MG. Revista Árvore 28 (3): 397-405.

[63] Sobral, M. (2014): Flora do Brasil 2020. Jardim Botânico do Rio de Janeiro. Eugenia. http://reflora.jbrj.gov.br/reflora/floradobrasil/FB10400. (Accessed: 28 Sept 2016)

[64] Souza, L.F. (2016): Flora do Brasil 2020. Jardim Botânico do Rio de Janeiro. Vochysiaceae. http://reflora.jbrj.gov.br/reflora/floradobrasil/FB15285. (Accessed: 29 Setpt 2016)

[65] Souza, V. C., Lorenzi, H. (2012). Botânica sistemática: guia ilustrado para identificação das famílias de fanerógamas nativas e exóticas no Brasil, baseado em APG III, 3rd Edition. - Brazil: Instituto Plantarum, Nova Odessa 768 p.

[66] Stefano, M.V. (2012): Flora do Brasil 2020. Jardim Botânico do Rio de Janeiro. Meliaceae. http://reflora.jbrj.gov.br/reflora/floradobrasil/FB10002. (Accessed: 29 Sept 2016)

[67] Tabarelli, M., Villani, J. P., Mantovani, W. (1993): Aspectos da sucessão secundária em trecho da floresta atlântica no Parque Estadual da Serra do Mar, SP. - Revista do Instituto Florestal 5: 101-114.

[68] Teixeira, A. P., Assis, M. A. (2003): Comparação da abundância das principais espécies de Mata Paludosa e Estacional Semidecidual em um fragmento florestal no interior paulista. - In: Anais do Congresso de Ecologia do Brasil 6: 412-413. (In Brazil)

[69] Barbosa, L.M., Lieberg, S. A. (1998): Proposta metodológica de enriquecimento florístico no parque Ecológico do Guarapiranga - SP. - In Anais do Simpósio de Ecossistemas Brasileiros 4: 250-256. (In Brazil)

[70] The Field Museum (2016): Neotropical Herbarium Specimens 1999-2016. Chicago, Illinois. http://fm1.fieldmuseum.org/vrrc/. (Accessed: 29 May 2015)

[71] The New York Botanical Garden. (2016): International Plant Science Center. The C. V. Starr Virtual Hebarium. New York. htpp://sciweb.nybg.org/Science2/vii2.asp. (Accessed: 29 Sept 2016).

[72] Torres, R. B., Matthes, L. A. F., Rodrigues, R. R., Leitão Filho, H. F. (1992): Espécies florestais nativas para plantio em áreas de brejo. - O Agronômico 44(1/3): 1-2.

[73] Tropicos.org. (2016): Missouri Botanical Garden. Saint Louis, Missouri. http://www.tropicos.org. (Accessed: 29 May 2015)

[74] Viana, J. H. M., Costa, A. M., Ribeiro, A., Schuler, A. E. (2015): Tandem-X derived DEM applied to the modelling of a small rural catchment and the impact assessment of urbanization on its water quality. https://tandemx-science.dlr.de/cgibin/wcm.pl?page=proposals_summary_IntermediateDEM;id=93. (Accessed: 28 May 2015). 
[75] Vilela, E. A., Oliveira Filho, A. T., Carvalho, D. A., Guilherme, F. A. G., Appolinário, V. (2001): Caracterização estrutural de floresta ripária do Alto Rio Grande, em Madre de Deus de Minas, MG. - Cerne 6(2): 41-54.

[76] Zappi, D. (2014): Flora do Brasil 2020. Jardim Botânico do Rio de Janeiro. Rubiaceae. http://reflora.jbrj.gov.br/reflora/floradobrasil/FB14167. (Accessed: 29 Sept. 2016).

\section{ANNEXES}

Table 1. Physical parameters: altitude (z), distance from the stream (Dist), difference of altitude between the point and the stream (Dif), slope in degrees (Decl), sun exposure in azimuth (Aspec), runoff (runoff), for the soil sampling points, coordinates UTM Zone 23/WGS 84

\begin{tabular}{c|c|c|c|c|c|c|c|c}
\hline POINT & $\mathbf{x}(\mathbf{m})$ & $\mathbf{y}(\mathbf{m})$ & $\mathbf{z}(\mathbf{m})$ & dist $(\mathbf{m})$ & dif $(\mathbf{m})$ & decl $(\mathbf{m})$ & aspec & runoff \\
\hline 1 & 575656 & 7849054 & 939 & 17 & 1 & 17 & 180 & 9 \\
\hline 9 & 575725 & 7849113 & 950 & 43 & 9 & 17 & 135 & 1 \\
\hline 19 & 575810 & 7849151 & 942 & 12 & -2 & 6 & 135 & 2 \\
\hline 28 & 575835 & 7849231 & 948 & 0 & 0 & 8 & 180 & 3266 \\
\hline 39 & 575673 & 7849101 & 952 & 39 & 15 & 19 & 180 & 1 \\
\hline 43 & 575696 & 7849135 & 962 & 74 & 24 & 8 & 180 & 1 \\
\hline 47 & 575703 & 7849177 & 959 & 102 & 18 & 3 & 270 & 1 \\
\hline 51 & 575690 & 7849205 & 964 & 120 & 19 & 11 & 180 & 1 \\
\hline 56 & 575657 & 7849129 & 957 & 71 & 20 & 7 & 0 & 1 \\
\hline 60 & 575683 & 7849168 & 958 & 112 & 15 & 8 & 135 & 436 \\
\hline 65 & 575654 & 7849234 & 974 & 160 & 23 & 9 & 135 & 1 \\
\hline 68 & 575639 & 7849275 & 978 & 185 & 20 & 12 & 180 & 1 \\
\hline
\end{tabular}

Table 2. Mean grain size among the three depths $(0-10,10-20,20-30 \mathrm{~cm})$ : fine sand (sand), coarse sand (csand), clay, silt, particle density (DensP), macro-porosity, micro-porosity and total porosity (poreden)

\begin{tabular}{|c|c|c|c|c|c|c|c|c|}
\hline POINT & sand & csand & clay & silt & \multirow{2}{*}{$\begin{array}{c}\text { DensP } \\
\mathrm{g} / \mathrm{cm}^{3}\end{array}$} & macrop & microp & \multirow[t]{2}{*}{ poreden } \\
\hline & \multicolumn{4}{|c|}{ 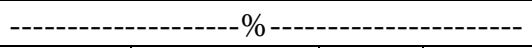 } & & \multicolumn{2}{|c|}{----------\%---------- } & \\
\hline 1 & 3 & 4 & 38 & 55 & 2,24 & 19,2 & 40,3 & 59,5 \\
\hline 9 & 8 & 1 & 33 & 57 & 2,33 & 9,9 & 46,5 & 56,4 \\
\hline 19 & 4 & 2 & 36 & 58 & 2,25 & 12,4 & 41,5 & 53,9 \\
\hline 28 & 4 & 3 & 30 & 63 & 2,29 & 14,2 & 37,7 & 51,9 \\
\hline 39 & 3 & 2 & 45 & 50 & 2,21 & 19,2 & 34,3 & 53,5 \\
\hline 43 & 3 & 3 & 44 & 51 & 2,30 & 16,4 & 38,3 & 54,7 \\
\hline 47 & 3 & 3 & 46 & 48 & 2,25 & 16,4 & 37,3 & 53,7 \\
\hline 51 & 3 & 2 & 49 & 45 & 2,23 & 20,0 & 33,6 & 53,6 \\
\hline 56 & 3 & 3 & 45 & 49 & 2,13 & 15,5 & 35,5 & 51,0 \\
\hline 60 & 3 & 3 & 46 & 48 & 2,29 & 15,3 & 37,8 & 53,1 \\
\hline 65 & 3 & 2 & 48 & 48 & 2,26 & 16,5 & 34,9 & 51,4 \\
\hline 68 & 2 & 2 & 49 & 47 & 2,26 & 16,6 & 37,8 & 54,4 \\
\hline
\end{tabular}


Table 3. Mean fertility values among the three layers $(0-10,10-20,20-30 \mathrm{~cm})$ : phosphorus $(P)$, potassium (K), aluminum (Al), calcium $(\mathrm{Ca})$, magnesium $(\mathrm{Mg})$, Cation Exchange Capacity (CEC), Hydrogen + Aluminium $(H+A l)$ Sum of Bases (SB), Saturation by Aluminum (m), Bases Saturation (v), Copper (Cu), Iron ( $F e$ ), Manganese (Mn), Zinc ( $\mathrm{Zn})$, pH and organic matter (om)

\begin{tabular}{|c|c|c|c|c|c|c|c|c|c|c|c|c|c|c|c|c|}
\hline \multirow[t]{2}{*}{ POINT } & $\mathbf{P}$ & $\mathbf{K}$ & Al & $\mathrm{Ca}$ & Mg & CEC & $\mathbf{H}+\mathbf{A l}$ & SB & $\mathbf{m}$ & $\mathbf{v}$ & $\mathbf{C u}$ & $\mathbf{F e}$ & Mn & $\mathbf{Z n}$ & \multirow[t]{2}{*}{$\mathrm{pH}_{\mathrm{H} 2 \mathrm{O}}$} & \multirow{2}{*}{\begin{tabular}{|c|} 
om \\
Dag/kg \\
\end{tabular}} \\
\hline & \multicolumn{2}{|c|}{-----mg/dm ${ }^{3}-----$} & \multicolumn{6}{|c|}{ 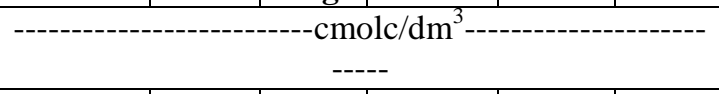 } & $-----\%$ & ---- & \multicolumn{4}{|c|}{$\begin{array}{c}\text {--------------mg/dm } \\
-\end{array}$} & & \\
\hline 1 & 2.78 & 58 & 1.95 & 2.20 & 0.44 & 9.98 & 12.3 & 2.78 & 31.45 & 18 & 0.84 & 89.70 & 20.72 & 0.84 & 6.7 & 4.01 \\
\hline 9 & 3.81 & 50 & 0.30 & 5.89 & 0.77 & 10.71 & 3.9 & 6.79 & 5.60 & 62 & 3.42 & 870.50 & 74.64 & 2.45 & 5.7 & 3.86 \\
\hline 19 & 7.48 & 63 & 3.17 & 1.29 & 0.25 & 10.22 & 8.5 & 1.70 & 65.27 & 17 & 3.21 & 386.00 & 21.47 & 1.69 & 5.0 & 2.74 \\
\hline 28 & 2.92 & 51 & 3.29 & 1.27 & 0.41 & 8.36 & 6.5 & 1.81 & 65.44 & 21 & 1.63 & 124.37 & 59.06 & 0.65 & 4.7 & 3.05 \\
\hline 39 & 2.02 & 60 & 5.67 & 0.85 & 0.22 & 10.67 & 9.4 & 1.23 & 81.89 & 12 & 1.32 & 95.79 & 27.60 & 0.73 & 4.6 & 3.73 \\
\hline 43 & 1.74 & 97 & 3.30 & 1.85 & 0.49 & 8.73 & 6.1 & 2.59 & 62.20 & 28 & 1.23 & 80.90 & 51.52 & 0.63 & 5.4 & 3.50 \\
\hline 47 & 1.74 & 104 & 3.92 & 3.46 & 0.63 & 12.03 & 7.7 & 4.35 & 48.62 & 36 & 1.19 & 88.39 & 61.29 & 1.23 & 5.2 & 4.23 \\
\hline 51 & 2.07 & 73 & 5.48 & 2.70 & 0.51 & 13.96 & 10.6 & 3.40 & 64.87 & 22 & 1.27 & 177.53 & 46.17 & 1.50 & 4.8 & 5.23 \\
\hline 56 & 2.06 & 80 & 3.74 & 1.55 & 0.50 & 9.81 & 7.6 & 2.26 & 65.91 & 23 & 1.05 & 82.44 & 32.00 & 0.21 & 5.6 & 3.80 \\
\hline 60 & 2.50 & 97 & 5.06 & 1.12 & 0.25 & 14.91 & 13.3 & 1.62 & 76.65 & 10 & 1.15 & 108.86 & 49.37 & 0.55 & 5.4 & 4.19 \\
\hline 65 & 2.26 & 97 & 4.77 & 1.79 & 0.29 & 10.98 & 8.7 & 2.33 & 67.22 & 22 & 0.70 & 126.63 & 25.14 & 0.59 & 5.5 & 3.62 \\
\hline 68 & 2.68 & 85 & 4.03 & 2.54 & 0.52 & 12.21 & 8.9 & 3.29 & 55.13 & 27 & 1.40 & 154.96 & 38.09 & 1.20 & 5.4 & 3.86 \\
\hline
\end{tabular}


Table 4. Pearson Correlation among the hydrographic parameter (distance from the stream, dist), topographic parameters ( $z$, slope, aspect, runoff),

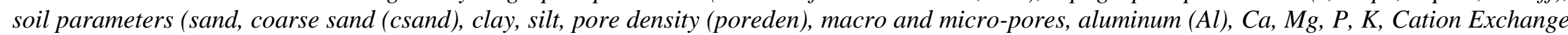
Capacity (CEC), $H+A l$, sum of bases (SB), aluminum saturation (m), base saturation (V), micro-nutrients ( $\mathrm{Cu}, \mathrm{Fe}, \mathrm{Mn}, \mathrm{Zn}, \mathrm{pH})$, organic matter (om), in the first $10 \mathrm{~cm}$ of soil ( $n=12)$

\begin{tabular}{|c|c|c|c|c|c|c|c|c|c|c|c|c|c|c|c|c|c|c|c|c|c|c|c|c|c|c|c|}
\hline Variables & dist & slope & aspec & runoff & sand & csand & clay & silt & poreden & macrop & microp & Al & $\mathbf{C a}$ & $\mathbf{M g}$ & $\mathbf{P}$ & $\mathbf{K}$ & CEC & H+Al & SB & $\mathbf{m}$ & V & $\mathbf{C u}$ & $\mathbf{F e}$ & Mn & $\mathbf{Z n}$ & pH & om \\
\hline $\mathrm{z}$ & 0.95 & -0.21 & 0.04 & -0.24 & 0.34 & -0.30 & 0.74 & 0.71 & 0.46 & 0.10 & -0.56 & 0.36 & 0.02 & 0.10 & 0.55 & 0.41 & -0.01 & 0.00 & 0.02 & 0.10 & \begin{tabular}{|l|}
0.04 \\
\end{tabular} & 0.34 & 0.30 & 0.05 & 0.09 & 0.03 & 0.29 \\
\hline dist & & -0.19 & 0.07 & -0.39 & 0.33 & -0.20 & 0.81 & 0.81 & 0.31 & 0.04 & -0.45 & 0.41 & 0.03 & 0.09 & 0.44 & 0.52 & 0.19 & 0.17 & 0.03 & 0.10 & 0.01 & 0.35 & 0.28 & 0.01 & 0.02 & 0.18 & 0.43 \\
\hline slope & & & 0.03 & -0.15 & 0.37 & 0.29 & 0.23 & 0.11 & -0.06 & -0.37 & 0.58 & 0.13 & 0.29 & 0.18 & 0.08 & 0.52 & 0.33 & 0.12 & 0.27 & 0.21 & 0.09 & 0.13 & 0.28 & 0.06 & 0.45 & 0.22 & 0.27 \\
\hline aspec & & & & 0.10 & 0.15 & 0.21 & 0.03 & 0.01 & 0.11 & 0.15 & 0.11 & 0.02 & 0.19 & 0.09 & 0.18 & 0.02 & 0.28 & 0.13 & 0.18 & 0.10 & 0.02 & 0.13 & 0.13 & 0.43 & 0.34 & 0.24 & 0.24 \\
\hline runoff & & & & & 0.10 & 0.04 & 0.54 & 0.66 & 0.44 & 0.01 & -0.06 & 0.07 & 0.25 & 0.16 & 0.06 & 0.32 & -0.08 & 0.12 & 0.25 & 0.09 & 0.23 & 0.01 & 0.11 & 0.34 & 0.26 & 0.24 & 0.45 \\
\hline sand & & & & & & -0.42 & 0.60 & 0.44 & 0.13 & -0.48 & 0.55 & 0.70 & 0.55 & 0.33 & 0.16 & 0.50 & 0.00 & -0.40 & 0.52 & 0.55 & 0.52 & \begin{tabular}{|l|}
0.70 \\
\end{tabular} & 0.91 & 0.35 & 0.56 & 0.29 & 0.17 \\
\hline csand & & & & & & & 0.03 & 0.04 & -0.48 & 0.30 & 0.31 & 0.00 & 0.18 & 0.41 & 0.11 & \begin{tabular}{|l|}
0.19 \\
\end{tabular} & 0.46 & 0.28 & 0.21 & 0.20 & 0.04 & 0.53 & 0.55 & 0.03 & 0.05 & 0.27 & 0.49 \\
\hline clay & & & & & & & & 0.98 & -0.20 & 0.31 & -0.66 & 0.67 & 0.15 & 0.15 & $\begin{array}{r}- \\
0.41 \\
\end{array}$ & 0.67 & 0.20 & 0.30 & 0.13 & 0.32 & 0.17 & $\begin{array}{r}- \\
0.57\end{array}$ & $\begin{array}{r}- \\
0.58\end{array}$ & 0.20 & 0.23 & $\begin{array}{r}- \\
0.14 \\
\end{array}$ & 0.59 \\
\hline silt & & & & & & & & & 0.25 & -0.25 & 0.54 & 0.56 & 0.03 & 0.01 & 0.44 & 0.64 & -0.29 & -0.26 & 0.04 & 0.16 & 0.03 & 0.51 & 0.46 & 0.12 & 0.10 & 0.03 & 0.70 \\
\hline poreden & & & & & & & & & & -0.21 & -0.02 & 0.12 & 0.08 & 0.22 & 0.13 & 0.19 & -0.25 & -0.17 & 0.11 & 0.01 & 0.01 & 0.16 & 0.21 & 0.19 & 0.02 & 0.15 & 0.40 \\
\hline macrop & & & & & & & & & & & -0.46 & 0.22 & 0.15 & 0.08 & 0.55 & 0.40 & -0.30 & $-0.21 \mid$ & 0.11 & 0.07 & 0.11 & \begin{tabular}{|l|} 
\\
\end{tabular} & 0.71 & 0.07 & 0.72 & 0.14 & 0.15 \\
\hline microp & & & & & & & & & & & & $\begin{array}{r}- \\
0.63 \\
\end{array}$ & 0.41 & 0.34 & 0.49 & 0.42 & 0.20 & -0.10 & 0.39 & 0.46 & 0.25 & \begin{tabular}{|l|} 
\\
\end{tabular} & 0.57 & 0.02 & \begin{tabular}{|l|}
0.62 \\
\end{tabular} & \begin{tabular}{|l|}
0.59 \\
\end{tabular} & 0.09 \\
\hline $\mathrm{Al}$ & & & & & & & & & & & & & 0.71 & 0.72 & 0.02 & 0.34 & 0.13 & 0.68 & 0.71 & 0.86 & 0.80 & 0.49 & 0.60 & 0.42 & 0.46 & 0.46 & 0.18 \\
\hline $\mathrm{Ca}$ & & & & & & & & & & & & & & 0.92 & $\begin{array}{r}- \\
0.40^{-} \\
\end{array}$ & 0.10 & 0.38 & \begin{tabular}{|l|} 
\\
\end{tabular} & 1.00 & O.95 & \begin{tabular}{|l|} 
\\
\end{tabular} & 0.13 & 0.36 & 0.59 & 0.62 & 0.46 & 0.50 \\
\hline $\mathrm{Mg}$ & & & & & & & & & & & & & & & $0.45^{-}$ & $0.01^{-}$ & 0.25 & -0.48 & 0.94 & 0.95 & \begin{tabular}{|l|}
0.90 \\
\end{tabular} & 0.05 & 0.11 & 0.49 & 0.38 & 0.44 & 0.47 \\
\hline $\mathrm{P}$ & & & & & & & & & & & & & & & & $\begin{array}{r}- \\
0.27 \\
\end{array}$ & \begin{tabular}{|l|} 
\\
\end{tabular} & 0.20 & 0.41 & 0.37 & 0.49 & \begin{tabular}{|l|} 
\\
\end{tabular} & 0.45 & 0.51 & 0.24 & 0.04 & 0.52 \\
\hline K & & & & & & & & & & & & & & & & & 0.27 & 0.31 & 0.06 & \begin{tabular}{|l|}
0.11 \\
\end{tabular} & 0.05 & 0.48 & 0.54 & 0.05 & 0.37 & 0.09 & 0.49 \\
\hline CEC & & & & & & & & & & & & & & & & & & 0.70 & 0.38 & \begin{tabular}{|l|}
0.19 \\
\end{tabular} & 0.04 & 0.12 & 0.06 & 0.42 & 0.42 & 0.18 & 0.76 \\
\hline
\end{tabular}




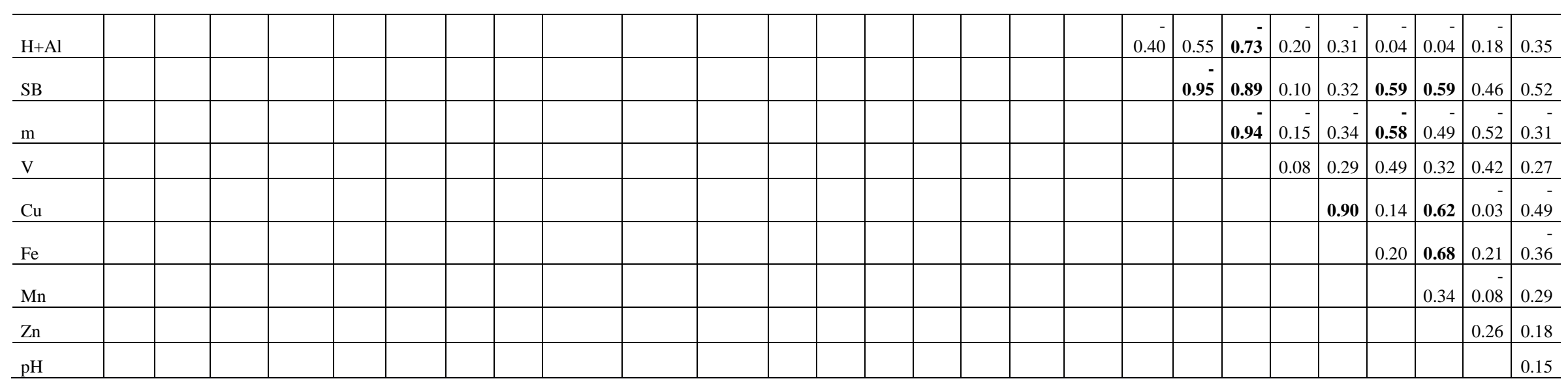


Table 5. Pearson Correlation among the hydrographic parameter (distance from the stream, dist), topographic parameters ( $z$, slope, aspect, runoff), soil parameters (sand, coarse sand (csand), clay, silt, pore density (poreden), macro and micro-pores, aluminum ( $A l), C a, M g, P, K$, Cation Exchange Capacity (CEC), $H+A l$, sum of bases (SB), aluminum saturation (m), base saturation (V), micro-nutrients ( $\mathrm{Cu}, \mathrm{Fe}, \mathrm{Mn}, \mathrm{Zn}, \mathrm{pH}$ ), organic matter (om), in the first $20 \mathrm{~cm}$ of soil

\begin{tabular}{|c|c|c|c|c|c|c|c|c|c|c|c|c|c|c|c|c|c|c|c|c|c|c|c|c|c|c|c|}
\hline Variables & dist & slope & aspec & runoff & sand & csand & clay & silt & poreden & macrop & microp & Al & $\mathrm{Ca}$ & $\mathbf{M g}$ & $\mathbf{P}$ & $\mathbf{K}$ & CEC & $\mathrm{H}+\mathrm{Al}$ & SB & $\mathbf{m}$ & $\mathbf{V}$ & $\mathbf{C u}$ & $\mathrm{Fe}$ & Mn & $\mathbf{Z n}$ & pH & om \\
\hline $\mathrm{z}$ & .95 & 0.21 & .04 & 0.24 & 0.29 & 0.33 & .75 & 0.76 & 0.42 & .34 & 0.23 & .41 & 0.08 & .05 & 0.43 & .61 & .03 & .06 & 0.05 & .17 & 0.07 & 0.45 & 0.26 & 0.07 & 0.26 & 0.08 & .06 \\
\hline dist & & 0.19 & .07 & 0.39 & 0.31 & 0.33 & .81 & 0.84 & 0.30 & .41 & 0.26 & .43 & 0.04 & .02 & 0.41 & .59 & .27 & .25 & 0.02 & .14 & 0.08 & 0.46 & 0.24 & 0.16 & 0.22 & .02 & .20 \\
\hline slope & & & .03 & 0.15 & .38 & 0.28 & 0.17 & .13 & .10 & .11 & 0.14 & 0.16 & .23 & .01 & 0.21 & 0.59 & .16 & .02 & .19 & 0.19 & .14 & .04 & .33 & 0.05 & .20 & 0.02 & .11 \\
\hline aspec & & & & .10 & 0.11 & .11 & .03 & 0.01 & .38 & .24 & 0.13 & .10 & .11 & 0.02 & 0.15 & .23 & 0.28 & 0.32 & .10 & 0.03 & .18 & 0.06 & 0.13 & .16 & .14 & 0.31 & .15 \\
\hline runoff & & & & & .04 & .52 & 0.57 & .60 & .06 & 0.32 & 0.02 & 0.04 & 0.19 & 0.09 & 0.01 & 0.37 & 0.44 & 0.26 & 0.19 & .15 & 0.09 & 0.01 & 0.12 & .30 & 0.15 & 0.36 & 0.35 \\
\hline sand & & & & & & 0.51 & 0.60 & .49 & .40 & 0.74 & .79 & 0.77 & .85 & .71 & .34 & 0.36 & .05 & 0.49 & .83 & 0.86 & .82 & .75 & .96 & .73 & .84 & .11 & .24 \\
\hline csand & & & & & & & 0.22 & .26 & .01 & .09 & 0.37 & .17 & 0.53 & 0.38 & 0.28 & 0.10 & 0.02 & .32 & 0.52 & .47 & 0.51 & 0.52 & 0.65 & 0.19 & 0.65 & .22 & 0.34 \\
\hline clay & & & & & & & & 0.99 & 0.35 & .67 & 0.55 & .69 & 0.35 & 0.28 & 0.51 & .58 & .21 & .40 & 0.33 & .46 & 0.39 & 0.58 & 0.50 & 0.41 & 0.44 & 0.04 & .31 \\
\hline silt & & & & & & & & & .29 & 0.59 & .47 & 0.62 & .24 & .18 & .55 & 0.58 & 0.27 & 0.38 & .22 & 0.36 & .30 & .55 & .41 & .30 & .37 & 0.03 & 0.40 \\
\hline poreden & & & & & & & & & & 0.29 & .36 & 0.28 & .26 & .02 & .26 & 0.16 & 0.09 & 0.22 & .23 & 0.24 & .25 & .42 & .41 & .47 & .43 & 0.03 & .30 \\
\hline macrop & & & & & & & & & & & 0.84 & .83 & 0.61 & 0.63 & 0.37 & .06 & .16 & .53 & 0.61 & .68 & 0.66 & 0.64 & 0.62 & \begin{tabular}{|l|}
0.74 \\
\end{tabular} & 0.46 & 0.33 & .15 \\
\hline microp & & & & & & & & & & & & $\mathbf{0 . 8 8}$ & .77 & .77 & .60 & .04 & 0.14 & 0.63 & .78 & 0.85 & .83 & .82 & .78 & .70 & .71 & .27 & 0.04 \\
\hline $\mathrm{Al}$ & & & & & & & & & & & & & 0.78 & $\mathbf{0 . 7 6}$ & 0.46 & .17 & .06 & .55 & 0.78 & .87 & 0.81 & 0.70 & 0.69 & \begin{tabular}{|l|}
0.58 \\
\end{tabular} & 0.57 & 0.42 & .20 \\
\hline $\mathrm{Ca}$ & & & & & & & & & & & & & & .91 & .24 & 0.06 & .19 & 0.47 & .00 & 0.98 & .97 & .64 & .83 & .66 & .82 & .23 & .33 \\
\hline $\mathrm{Mg}$ & & & & & & & & & & & & & & & .14 & .05 & .08 & 0.52 & .93 & 0.92 & .92 & .51 & .65 & .70 & .62 & .27 & .21 \\
\hline $\mathrm{P}$ & & & & & & & & & & & & & & & & 0.15 & 0.20 & 0.33 & .23 & 0.36 & .30 & .80 & .50 & .03 & .56 & 0.13 & 0.28 \\
\hline $\mathrm{K}$ & & & & & & & & & & & & & & & & & 0.11 & 0.09 & 0.02 & .10 & .01 & 0.23 & 0.32 & .01 & 0.23 & .26 & 0.07 \\
\hline CEC & & & & & & & & & & & & & & & & & & .77 & .18 & 0.14 & 0.04 & 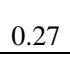 & .10 & 0.28 & .04 & .54 & .43 \\
\hline $\mathrm{H}+\mathrm{Al}$ & & & & & & & & & & & & & & & & & & & 0.48 & .51 & 0.66 & 0.64 & 0.43 & 0.68 & 0.48 & .32 & .18 \\
\hline
\end{tabular}




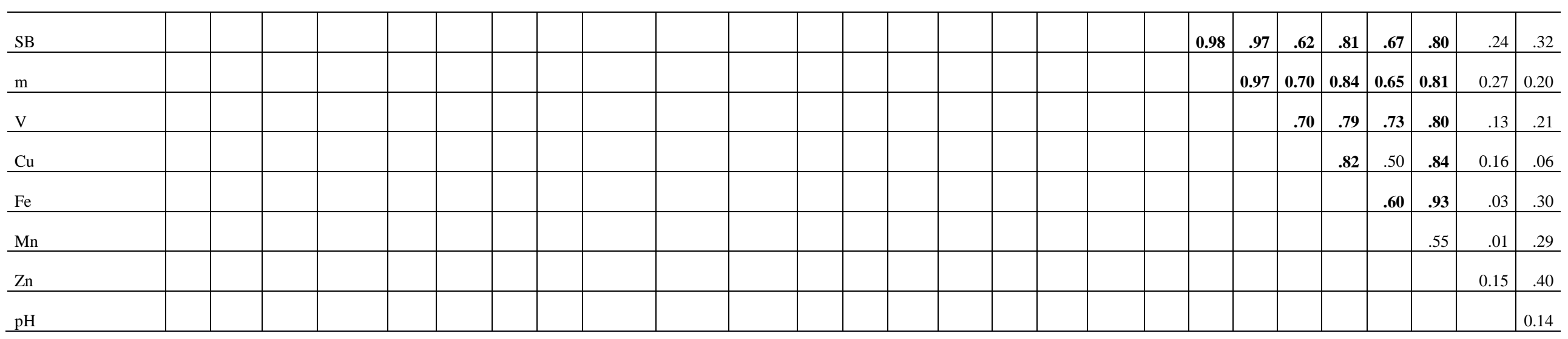


Table 6. Pearson Correlation among the hydrographic parameter (distance from the stream, dist), topographic parameters (z, slope, aspect, runoff), soil parameters (sand, coarse sand (csand), clay, silt, pore density (poreden), macro and micro-pores, aluminum (Al), Ca, Mg, P, K, Cation Exchange Capacity $(C E C), H+A l$, sum of bases $(S B)$, aluminum saturation (m), base saturation (V), micro-nutrients $(\mathrm{Cu}, \mathrm{Fe}, \mathrm{Mn}, \mathrm{Zn}, \mathrm{pH})$, organic matter (om), in the first $30 \mathrm{~cm}$ of soil

\begin{tabular}{|c|c|c|c|c|c|c|c|c|c|c|c|c|c|c|c|c|c|c|c|c|c|c|c|c|c|c|c|}
\hline Variables & dist & slope & aspec & runoff & sand & csand & clay & silt & poreden & macrop & microp & Al & $\mathrm{Ca}$ & Mg & $\mathbf{P}$ & $\mathbf{K}$ & CEC & $\mathrm{H}+\mathrm{Al}$ & SB & $\mathbf{m}$ & $\mathbf{V}$ & $\mathrm{Cu}$ & $\mathrm{Fe}$ & Mn & $\mathbf{Z n}$ & pH & om \\
\hline$z$ & 0.95 & -0.21 & 0.04 & -0.24 & 0.45 & -0.43 & $\mathbf{0 . 7 8}$ & 0.76 & 0.15 & 0.10 & -0.21 & 0.30 & 0.16 & 0.34 & 0.40 & 0.81 & 0.53 & -0.09 & 0.39 & 0.05 & 0.02 & 0.44 & 0.22 & 0.22 & 0.15 & 0.33 & 0.49 \\
\hline dist & & -0.19 & 0.07 & -0.39 & 0.48 & -0.44 & 0.84 & 0.83 & 0.09 & 0.16 & -0.20 & 0.31 & 0.26 & 0.40 & 0.36 & \begin{tabular}{|l|l|} 
\\
\end{tabular} & 0.53 & 0.11 & 0.42 & 0.02 & 0.02 & 0.46 & 0.20 & 0.14 & 0.12 & 0.15 & 0.59 \\
\hline slope & & & 0.03 & -0.15 & 0.38 & -0.33 & 0.11 & 0.08 & 0.20 & 0.51 & -0.31 & 0.02 & 0.27 & 0.05 & 0.16 & 0.55 & -0.36 & 0.08 & 0.01 & 0.32 & 0.37 & 0.15 & 0.38 & 0.13 & 0.02 & 0.33 & 0.14 \\
\hline aspec & & & & 0.10 & 0.08 & -0.26 & 0.08 & 0.04 & 0.41 & 0.24 & -0.11 & 0.21 & 0.25 & 0.47 & 0.12 & 0.10 & 0.16 & 0.28 & 0.20 & 0.10 & 0.08 & 0.06 & 0.13 & 0.19 & 0.24 & 0.05 & 0.10 \\
\hline runoff & & & & & 0.18 & 0.37 & 0.58 & 0.60 & 0.01 & -0.12 & 0.06 & 0.14 & 0.24 & 0.07 & 0.10 & 0.28 & -0.18 & -0.30 & 0.16 & 0.12 & 0.08 & 0.04 & 0.13 & 0.27 & 0.20 & 0.32 & 0.19 \\
\hline sand & & & & & & -0.43 & 0.63 & 0.56 & 0.32 & -0.37 & 0.62 & 0.77 & 0.53 & 0.24 & 0.38 & 0.57 & \begin{tabular}{|l|} 
\\
\end{tabular} & \begin{tabular}{|c|}
-0.63 \\
\end{tabular} & 0.46 & 0.75 & 0.77 & 0.76 & 0.87 & \begin{tabular}{|l|}
0.62 \\
\end{tabular} & 0.57 & 0.03 & 0.22 \\
\hline csand & & & & & & & $0.32^{-}$ & 0.36 & -0.56 & 0.04 & -0.30 & 0.20 & $\begin{array}{r} \\
0.69 \\
\end{array}$ & 0.41 & 0.14 & 0.24 & \begin{tabular}{|l|} 
\\
\end{tabular} & 0.29 & $\begin{array}{r} \\
0.73 \\
\end{array}$ & 0.63 & $\begin{array}{r}0.66 \\
\end{array}$ & 0.23 & 0.56 & $\begin{array}{r}- \\
0.64 \\
\end{array}$ & 0.46 & 0.20 & 0.24 \\
\hline clay & & & & & & & & $\begin{array}{r}- \\
0.99 \\
\end{array}$ & -0.21 & 0.46 & -0.46 & 0.66 & 0.09 & 0.08 & $\begin{array}{r}- \\
0.60 \\
\end{array}$ & \begin{tabular}{|l|} 
\\
\end{tabular} & 0.53 & 0.37 & 0.06 & 0.34 & 0.32 & 0.67 & 0.45 & 0.10 & 0.30 & 0.10 & 0.65 \\
\hline silt & & & & & & & & & 0.23 & -0.46 & 0.44 & 0.62 & 0.05 & 0.11 & \begin{tabular}{|l|}
0.60 \\
\end{tabular} & 0.76 & \begin{tabular}{|l|} 
\\
\end{tabular} & -0.32 & 0.10 & 0.29 & 0.26 & 0.64 & 0.39 & 0.05 & 0.28 & 0.09 & 0.68 \\
\hline poreden & & & & & & & & & & -0.36 & 0.37 & 0.43 & 0.54 & 0.20 & \begin{tabular}{|l|}
0.09 \\
\end{tabular} & 0.02 & \begin{tabular}{|l|} 
\\
\end{tabular} & -0.29 & 0.47 & 0.55 & 0.55 & 0.32 & 0.44 & 0.37 & 0.37 & 0.02 & 0.37 \\
\hline macrop & & & & & & & & & & & -0.86 & 0.72 & 0.28 & 0.06 & 0.56 & 0.03 & \begin{tabular}{|l|} 
\\
\end{tabular} & 0.58 & 0.38 & 0.43 & 0.38 & 0.57 & 0.45 & 0.38 & 0.47 & 0.20 & 0.68 \\
\hline microp & & & & & & & & & & & & 0.77 & 0.43 & 0.12 & 0.52 & 0.12 & 0.11 & -0.48 & 0.48 & 0.59 & 0.53 & 0.70 & 0.64 & 0.61 & 0.62 & 0.12 & 0.52 \\
\hline $\mathrm{Al}$ & & & & & & & & & & & & & 0.61 & 0.31 & \begin{tabular}{|l|} 
\\
\end{tabular} & 0.40 & 0.64 & 0.79 & 0.57 & $\mathbf{0 . 8 0}$ & 0.78 & 0.77 & 0.82 & 0.56 & 0.62 & 0.44 & 0.34 \\
\hline $\mathrm{Ca}$ & & & & & & & & & & & & & & 0.73 & 0.41 & 0.01 & \begin{tabular}{|l|} 
\\
\end{tabular} & -0.39 & 1.00 & 0.95 & 0.93 & 0.55 & 0.77 & 0.53 & 0.73 & 0.43 & 0.16 \\
\hline $\mathrm{Mg}$ & & & & & & & & & & & & & & & 0.12 & 0.15 & 0.07 & -0.21 & 0.78 & 0.61 & 0.61 & 0.17 & 0.32 & 0.58 & 0.40 & 0.26 & 0.50 \\
\hline $\mathrm{P}$ & & & & & & & & & & & & & & & & 0.46 & 0.04 & -0.24 & 0.38 & 0.50 & 0.39 & 0.84 & 0.58 & 0.02 & 0.74 & 0.12 & 0.43 \\
\hline $\mathrm{K}$ & & & & & & & & & & & & & & & & & 0.48 & 0.05 & 0.21 & 0.23 & 0.21 & 0.61 & 0.44 & 0.17 & 0.25 & 0.22 & 0.39 \\
\hline CEC & & & & & & & & & & & & & & & & & & 0.15 & 0.33 & 0.27 & 0.37 & 0.03 & 0.12 & 0.18 & 0.26 & 0.73 & 0.15 \\
\hline
\end{tabular}




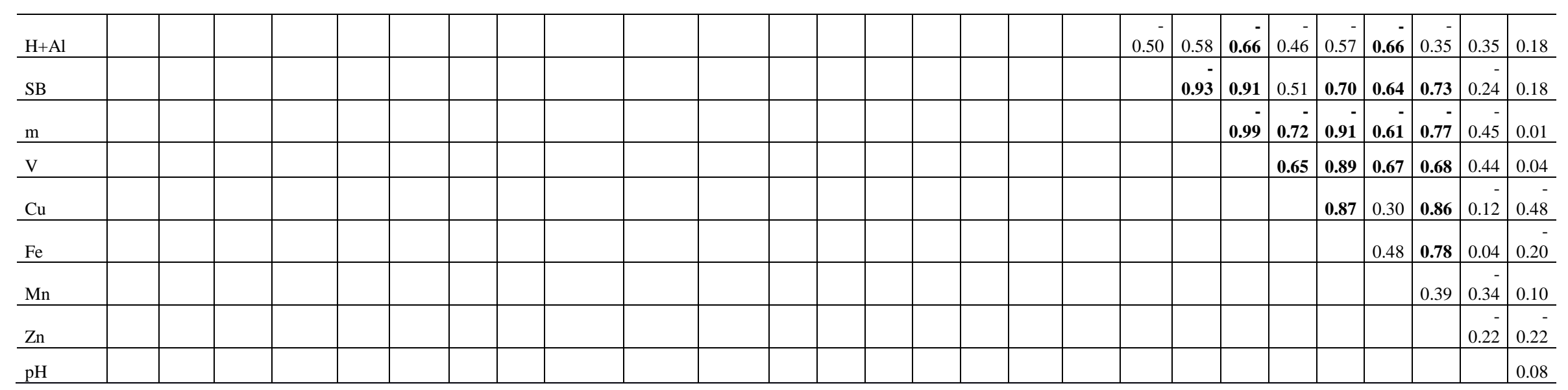

